\title{
Arctic Mackenzie Delta channel planform evolution during 1983-2013 utilising Landsat data and hydrological time series
}

\author{
Jenni-Mari Vesakoski ${ }^{1}$ (i) | Tua Nylén ${ }^{1}$ (i) | Berit Arheimer ${ }^{2}$ (i) | David Gustafsson ${ }^{2}$ । \\ Kristina Isberg ${ }^{2}$ | Markus Holopainen ${ }^{3}$ (i) | Juha Hyyppä ${ }^{4}$ (i) | Petteri Alho ${ }^{1,4}$
}

${ }^{1}$ Department of Geography and Geology, University of Turku, Fl-20014 Turku, Finland

${ }^{2}$ Hydrological Research, Swedish

Meteorological and Hydrological Institute (SMHI), SE-601 76 Norrköping, Sweden

${ }^{3}$ Department of Forest Sciences, University of Helsinki, PO Box 27, Fl-0014 Helsinki, Finland

${ }^{4}$ Finnish Geospatial Research Institute,

National Land Survey of Finland,

Geodeetininne 2, Fl-02430 Masala, Finland

Correspondence

Jenni-Mari Vesakoski, Department of

Geography and Geology, University of Turku,

Fl-20014 Turku, Finland.

Email: jmeves@utu.fi

Funding information

Doctoral programme in Biology, Geography and Geology, University of Turku; Academy of Finland, Grant/Award Number: 136234; Strategic Research Council, Academy of Finland, Grant/Award Number: 293389

\begin{abstract}
Arctic deltas, such as the Mackenzie Delta, are expected to face major climate change and increased human influence in the near future. Deltas are characterised by highly dynamic fluvial processes, and changing climate will cause considerable evolution of the riverine environment. The changes are difficult to predict with existing knowledge and data. This study quantified channel planform change of the Mackenzie Delta (1983-2013), analysing its temporal and spatial patterns. We addressed the main obstacle of research on large remote areas, the lack of data, by developing a unique work flow that utilised Landsat satellite imagery, hydrological time series, remote sensing-based change analysis, and automatic vectorisation of channels. Our results indicate that the Mackenzie Delta experienced constant evolution but at a highly varying rate over the 30 years. The study demonstrates that the magnitude and duration of flood peaks and the presence of spring ice breakup floods determine the rate of Arctic delta planform change. Changing winter conditions and spring flood magnitudes may therefore affect the stability of Arctic deltas. However, no clear trends towards decreased recurrence or magnitude of spring floods or increased instability of the delta plain have yet been observed in the Mackenzie Delta. The delta plain was most dynamic at the beginning and at the end of the examined period, corresponding to intense flooding, whereas the rates of change were subtle during the low-flood period 1994-2007. The largest changes have occurred along the wide Middle Channel and in the outermost delta. Relative to their size, however, smaller meandering channels have been highly dynamic. Hotspots of change in the delta plain are located in anastomosing and braiding channel segments and, at the local scale, in point bars and cut-banks along meandering channels. Our study describes how Landsat satellite data can be utilised for advancing fluvial geomorphological research in remote areas. However, cloudiness in the delta restricts production of dense time series with simultaneous coverage of the whole area and requires manual preprocessing.
\end{abstract}

\section{KEYWORDS}

change detection, climate change, discharge time series, fluvial geomorphology, remote sensing, river planform dynamics

\section{1 | INTRODUCTION}

Arctic deltas are among the world's most remote areas with least human impact (Walker, 1998). However, the situation is rapidly changing: Increasing interest in the Arctic for its natural resources and logistic and touristic values makes it a hotspot of future development (Schindler \& Smol, 2006; UNEP, 2007). The demanding natural conditions of the Arctic pose major challenges to modern development, highlighting the need for research and better predictability of the environment (Hagen, Vistad, Eide, Flyen, \& Fangel, 2012). For example, natural gas pipelines and permanent roads running south from the Arctic Ocean demand appropriate engineering to mitigate the effects of unstable ground (Williams \& Wallis, 1995; Wu, Sheng, Wang, Jin, \& Chen, 2010). Deltas are highly dynamic environments influenced by erosion, transportation, and sedimentation processes: A large meandering channel may rapidly change its course for a few hundred metres, particularly in exceptional discharge conditions. In the Arctic, the evolution of a delta is particularly difficult to predict 
because permafrost, seasonal discharge variation, and ice influence the stability of the channels (Kokelj \& Burn, 2005; Walker, 1999; Yang, Shi, $\&$ Marsh, 2015) and because climate change may have an unpredictable effect on discharge conditions (Lesack, Marsh, Hicks, \& Forbes, 2014; Marsh \& Hey, 1989; Palmer et al., 2008).

Despite the increasing interest in the Arctic and reports on its sensitivity to climate change (IPCC, 2015; Peterson et al., 2002; Schindler \& Smol, 2006), a limited amount of research has been targeted to Arctic fluvial geomorphology (see however, e.g., Alho \& Mäkinen, 2010; Beylich, 2008; Brooks, 2000; Carson, Conly, \& Jasper, 1999; Carson, Jasper, \& Conly, 1998; Jenner \& Hill, 1998; Lotsari, Wainwright, Corner, Alho, \& Käyhkö, 2014; Luck, Maumenee, \& Whited, 2010; McDonald \& Lamoureux, 2009; Walker \& Hudson, 2003). Much of the literature has relied on point measurements and extrapolation to larger areas (e.g., review by Carson et al., 1999). To our knowledge, no research has yet been published about channel planform changes in high latitudes that would consider long temporal and large spatial scales. Such work would require comparable datasets on the channel network spanning over decades and accurate reference data on river discharge and water level. Arctic deltas are difficult to access, and many are extremely complex and large in size, making it challenging to create time series of precise measurements. In addition, a lack of long continuous observational records of river discharge and water levels has hindered longitudinal studies of discharge conditions and the geomorphological response. The number of operational gauging stations is in fact decreasing in the Arctic (Shiklomanov, Lammers, \& Vörösmarty, 2002).

Over the past 40 years, remote sensing and particularly Landsat satellite imagery have boosted the research on fluvial geomorphology (Luck et al., 2010; Mertes, 2002). Since 1972, Landsat satellites have produced unmatched time series of raster images of the earth, including the previously inaccessible hinterlands. There now exists a 40-year-long archive of satellite images with at least a $60-\mathrm{m}$ resolution (30 m from 1986 onwards). These data enable cost-efficient longitudinal studies of patterns and process at a large spatial scale.

Several quantitative change detection methods-identifying objects, patterns, or phenomena and observing their change at different times (Lu, Mausel, Brondizio, \& Moran, 2004; Singh, 1989)-can be applied to the satellite image time series. The main obstacles for utilising passive optical satellite imagery (such as Landsat) are clouds that mask the ground and the large amount of data to select from. Although the cloud issue can be avoided with active sensors such as Synthetic Aperture Radar, their time series are still too short for studies of long temporal scales. Change detection methods based on satellite imagery have been successfully utilised in the mapping of riverine landscapes and water properties (Mertes, 2002). These methods have been previously applied, for example, to the rivers of the Amazon (e.g., Peixoto, Nelson, \& Wittmann, 2009; Rozo, Nogueira, \& Castro, 2014), China (e.g., Chu, Sun, Zhai, \& Xu, 2006; Yang et al., 2015), Europe (e.g., Alho, 2003; Henshaw, Gurnell, Bertoldi, \& Drake, 2013), and North America (e.g., Burge \& Lapointe, 2005; Joeckel \& Henebry, 2008). For example, Mouchot, Alföldi, De Lisle, and McCullough (1991) analysed channel connectivity patterns of the Arctic Mackenzie Delta utilising Landsat TM imagery in a snapshot study. However, due to the unique characteristics of the Arctic deltas, the applicability of remote sensing-based change detection methods in the Arctic requires further research.

River discharge is an important hydrological driver of the fluvial geomorphological processes, but the available observational data are often discontinuous, and the station network is sparse and reducing. Discontinuities in hydrological time series can be filled with hydrological modelling, even in watersheds that today lack gauging stations (Strömqvist, Arheimer, Dahné, Donnelly, \& Lindström, 2012). For example, the Hydrological Predictions for the Environment (HYPE) model by the Swedish Meteorological and Hydrological Institute (Lindström, Pers, Rosberg, Strömqvist, \& Arheimer, 2010) has produced simulated hydrological time series for the entire Arctic region (excluding Greenland; Arctic-HYPE). These data are crucial for the selection of comparable water level conditions for change analyses (Gilvear, 1999). They are also needed for selecting individual images with similar hydrological conditions to be able to create image mosaics with uniform water levels across a large area.

The aim of this study is to quantify large-scale changes in the channel planform of the Mackenzie Delta in western Arctic Canada over the last 30 years (1983-201), by utilising open-access datasets and a semi-automatic procedure. More specifically, we (a) quantify accumulation, erosion, and change in channel planform, including lateral migration, change in channel width, flow direction, sinuosity, and braiding; (b) analyse the influence of discharge magnitude and duration on the amount of channel evolution; and (c) locate hotspots of change across the entire delta plain. The large and complex Arctic delta is studied from a time series of Landsat satellite imagery, resulting in homogenous data for the entire delta. River discharge time series are utilised to detect past changes in discharge conditions, expected to be the main driver of channel planform evolution. The Mackenzie Delta is seen as a practical pilot for developing an efficient procedure for retrieving channel parameters for large remote riverine environments from Landsat data.

\section{2 | STUDY AREA}

The Mackenzie River initiates from the Great Slave Lake and flows $1,700 \mathrm{~km}$ through the Northwest Territories in northern Canada. It has a drainage basin of 1.8 million $\mathrm{km}^{2}$. The Mackenzie River drains into Beaufort Sea through an extensive $\left(13,000 \mathrm{~km}^{2}\right)$ Arctic delta, the Mackenzie Delta (Figure 1). The Mackenzie Delta is the world's second largest delta in the Arctic and one of the most studied (e.g., Burn \& Kokelj, 2009; Carson et al., 1998, 1999; Jenner \& Hill, 1998; Lesack \& Marsh, 2007; Mackay, 1963; Walker, 1998).

The Mackenzie Delta is an input-dominated delta (sediment input exceeding loss to offshore by $50 \%$; Carson et al., 1999) with mean sediment load in the silt-sized range (Hill, Lewis, Desmarais, Kauppamythoo, \& Rais, 2001). The Mackenzie River carries approximately 300 billion $\mathrm{m}^{3}$ of fresh water and $128 \mathrm{Mt}$ of sediment through the delta every year, and within-delta sediment exchange is also considerable (Carson et al., 1998, 1999). The average gradient of the delta plain being only $0.00005 \mathrm{~m} / \mathrm{m}$ (Hill et al., 2001); the sediment load has potential in causing major variation in the channel planform. Although the Mackenzie River is the main source of water in the delta, 
(a)

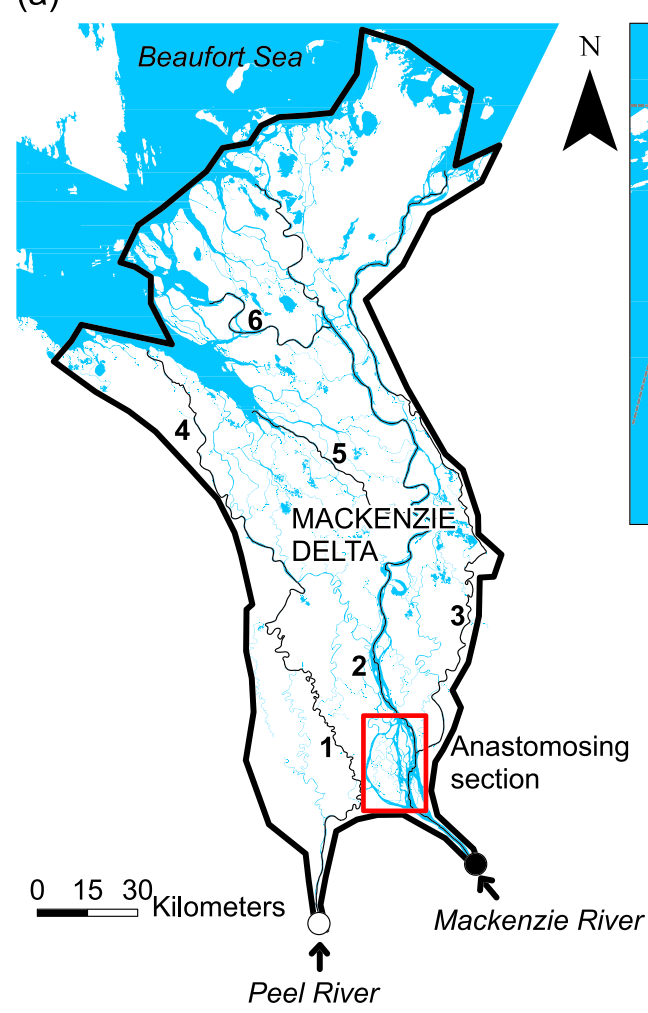

(b)

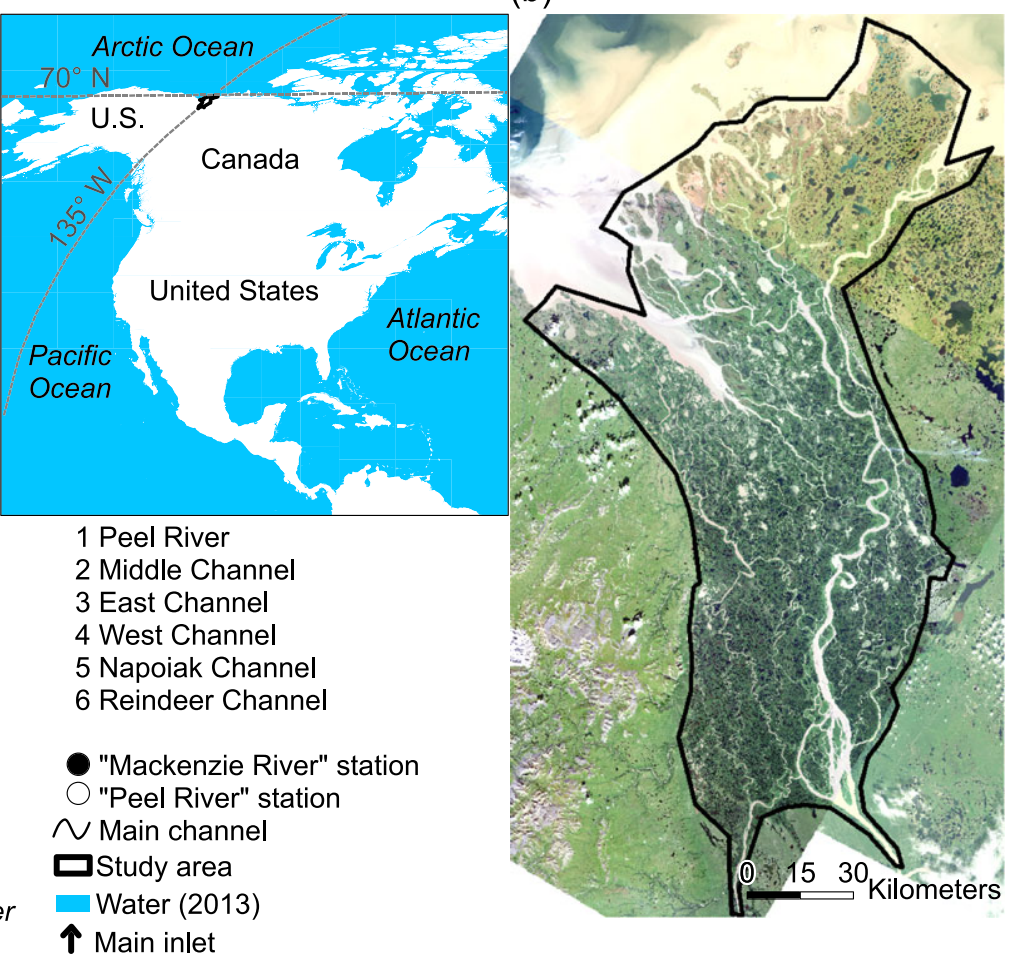

FIGURE 1 (a) Location of the study area of Mackenzie Delta, its main inlets and channels, and the river gauging stations. "Mackenzie River" station is the "Mackenzie River at Arctic Red River," and "Peel River" station the "Peel River above Fort McPherson" hydrological gauging station of the Water Survey of Canada. Lakes are not shown in (a). (b) True colour Landsat satellite image mosaic of the Mackenzie Delta in the late summer of 2013 (July 19/August 2/August 9; U.S. Geological Survey)

the smaller Peel River, with its inlet in the western part of the delta (Figure 1), has a significant effect on local hydrology (Hill et al., 2001). Its contribution to the total sediment load is $~ 17 \%$ (Carson et al., 1998). Due to discontinuous permafrost (Kokelj \& Burn, 2005; Nguyen, Burn, King, \& Smith, 2009) and local scale variation in channel bed and bank stability, the delta plain has a complex anastomosing and braiding channel network (Cordes, McLennan, \& Pearce, 1984; Hill et al., 2001) with tens of thousands of small lakes (Emmerton, Lesack, \& Marsh, 2007).

Discharge and associated sediment load have distinct seasonal variation. The delta plain and adjacent Beaufort Sea coast have snow and ice cover from October to May. Consequently, spring snowmelt results in sharp flood peaks, and water supply is minimal in the winter (Carson et al., 1998; Davies, 1975; Yang et al., 2015; Figure 2). Ice jams together with increased snowmelt during the spring ice breakup cause peak water levels, accentuated by the south-north flow direction (e.g., de Rham, Prowse, Beltaos, \& Lacroix, 2008). Overbank flow is typically an annual process, and two thirds of the lakes in the delta are flooded by the channels each year, mainly in spring and early summer (Marsh \& Hey, 1989).

Previous studies suggest that the average flow to the Mackenzie Delta or peak discharges have not changed significantly (Lesack, Marsh, Hicks, \& Forbes, 2013; Woo \& Thorne, 2003); but in response to climate warming, spring flood peaks have advanced for a few days,
FIGURE 2 Seasonal variation of discharge conditions and their year-to-year variability at "Mackenzie River at Arctic Red River" gauging station (Figure 1) and the peak discharge with 1-year recurrence interval. Year 1985 was characterised by one sharp snowmelt peak, year 1992 by extensive flooding for several weeks, and year 1995 by a lack of highdischarge conditions (data: HYDAT database, Water Survey of Canada)

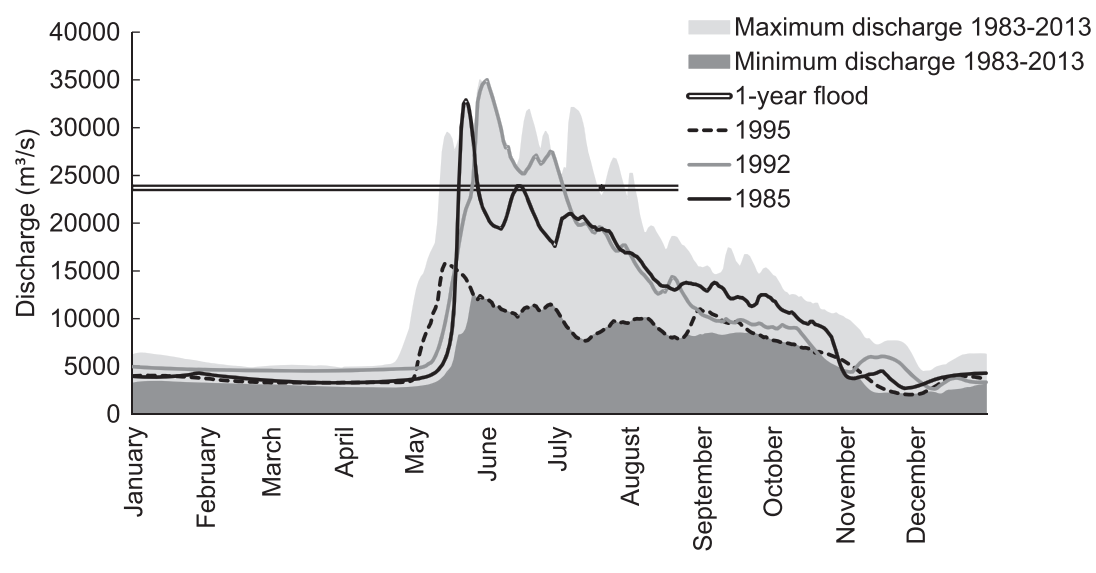


and winter base flow has increased over the past 30 years (Abdul Aziz \& Burn, 2006; Woo \& Thorne, 2003; Yang et al., 2015). Some studies report small decreases in the spring flood peak and summer discharge until ca. year 2010 (Abdul Aziz \& Burn, 2006; Yang et al., 2015). Decreased ice breakup floods and increased sea level have shortened overbank flow periods in the upper delta and lengthened them in the lower delta (Lesack \& Marsh, 2007).

Some previous studies claim that the delta plain has experienced minimal channel migration, because, for example, Cordes et al. (1984) found over-500-year-old spruce trees in the delta plain. On the contrary, Burn and Kokelj (2009) documented major migration of channels. Individual channels vary from braided and meandering ones to very straight (Figure 1). The Mackenzie Delta has six major channels: Peel River, Middle Channel, East Channel, West Channel, Napoiak Channel, and Reindeer Channel (Figure 1). Middle Channel is the longest, widest, and less sinuous than the smaller channels are but is the most braided.

\section{I DATA AND METHODS}

This paper describes a work flow for deriving land surface accumulation and erosion values for an Arctic delta, constructing the channel network in vector format and sampling the network for key channel variables. The work flow is described below and summarised in Figure 3.

\section{1 | River discharge and water level time series}

Discharge and water level data were used for selecting representative and comparable discharge periods for analysis. Discharge data were further utilised in quantifying variability in discharge conditions during the examined 30-year period (1983-2013; Figure 3).

Data from the gauging station "Mackenzie River at Arctic Red River" (Figure 1) of the Water Survey of Canada were used for quantifying discharge entering the Mackenzie Delta. We used discharge data for 1983-2013 from the HYDAT Database of the Water Survey of Canada. To fill gaps in the data (151 days in 1997-1998), we used simulated data from Arctic-HYPE model (version 2.4), developed by the Swedish Meteorological and Hydrological Institute (Lindström et al., 2010). Discharge of Peel River (at "Peel River above Fort McPherson" station; Figure 1) was not analysed in detail because it only accounted for $8 \%$ of the delta plain discharge and had strong association with the discharge patterns of the Mackenzie River (Pearson correlation of 0.89).

Water level data from the HYDAT Database were available from 2002 onwards. Water level for 1983-2001 was extrapolated from the discharge data at Mackenzie River at Arctic Red River using a discharge rating curve. A second-order polynomial curve $\left(R^{2}=.71\right)$ was fitted in the water level and discharge data (2002-2013), and the identified equation was used to calculate the water level for 1983-2001.

Flood was determined as discharge conditions exceeding the discharge of a 1-year flood at the Mackenzie River at Arctic Red River gauging station. The 1-year recurrence interval was chosen because

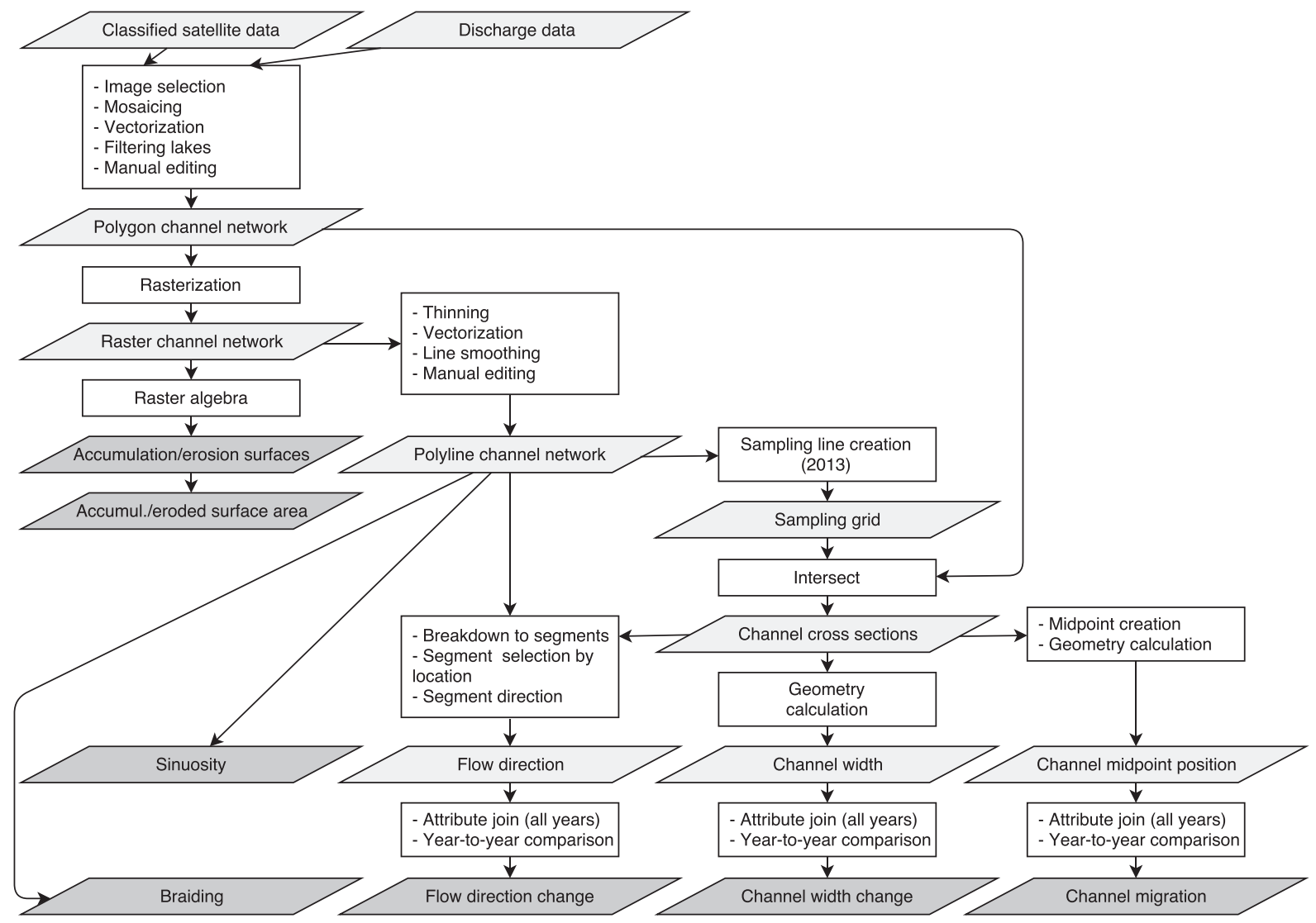

FIGURE 3 Simplified presentation of the work flow for determining delta planform change. Processes are visualised with white rectangles. Datasets are visualised with skewed rectangles, and final change variables highlighted with dark grey colour 
the river is known to flood almost annually (Marsh \& Hey, 1989). The discharge with 1-year recurrence interval was estimated using a discharge-frequency curve (following Dalrymple, 1960) on the basis of records for 1983-2013. The 1-year flood discharge was estimated at $23,700 \mathrm{~m}^{3} / \mathrm{s}$. Using this cut value, we calculated the number of flood days and the number of individual flood peaks during each hydrological year (September-August), that is, full years between each satellite image mosaic. Flood peaks were further divided into snowmelt and ice breakup floods (May 1 to 31, the appropriate period was visually checked from plotted hydrographic time series) and summer-autumn floods caused by rainfall events (June-October).

This approach accounted for large-scale variability in discharge conditions in the delta, caused by inflow through Mackenzie River at Arctic Red River gauging station, treating the delta as one homogenous unit. However, spatial variation in discharge conditions and, particularly, local effects of ice breakup flooding could not be taken into account with these data. Mackenzie River at Arctic Red River has previously been considered as the most suitable single gauging station for representing peak water levels in the delta, caused by inflow into the delta (Goulding, Prowse, \& Beltaos, 2009; Woo \& Thorne, 2003). Majority of the total outflow of the Mackenzie basin (95\%) passes this station. According to Goulding, Prowse, and Bonsal (2009), the peak breakup water levels at this station explain majority of the variability in peak water levels recorded other stations of the delta $\left(r^{2}=.57\right)$.

\subsection{Satellite data}

Satellite data were used to build raster image mosaics for the study area for each examined year and to derive vector (polygon and polyline) data of the channel network (Luck et al., 2010; Figure 3). The quality of the satellite data, mainly due to cloudiness, restricted the number of produced mosaics. The structure of the delta plain is highly sensitive to water level, and changes between successive images cannot be inferred unless water levels are known to be constant (Gilvear, 1999). Therefore, water level had to be similar between selected mosaics and even more so between individual images used for creating a mosaic. In total, six mosaics representing comparable autumn discharge conditions were selected: 1983, 1986, 1994, 2007, 2011, and 2013 (Table 1).

The mosaics were produced from passive optical Landsat satellite data. Details of the images used for creating the mosaics are specified in Table 1. For years 1986-2013, preclassified "Landsat Surface Reflectance Climate Data Record" (U.S. Geological Survey, 2016a) data were downloaded from the Earth Explorer database (http:// earthexplorer.usgs.goc/) of the U.S. Geological Survey. The raw reflectance values had been classified to surface water and dry land (and clouds, cloud shadows and snow, band "CFmask") by the U.S. Geological Survey (see U.S. Geological Survey, 2016a for details), which speeded up the postprocessing of the data. The accuracy of this classification was visually checked by comparing it to corresponding raw satellite images. The mosaic for 1983 was created from raw satellite images, downloaded from the Earth Explorer. Unsupervised classification, utilising near-infrared, red and green wavelengths (bands 4,3 , and 2 of Landsat $4 \mathrm{MSS}$ ), was used to classify the raw reflectance value patterns of 1983 into surface water and dry land.

All Landsat data had been orthorectified (using geodetic and elevation control data to correct position accuracy and relief deformations) and georeferenced by the U.S. Geological Survey by applying the standard Level 1 Product Generation System (see U.S. Geological Survey, 2016b for details). The preclassified "Landsat Surface Reflectance Climate Data Record" data (1986-2013) had also been atmospherically corrected by the U.S. Geological Survey by applying the Moderate Resolution Imaging Spectroradiometer atmospheric correction routine (see U.S. Geological Survey, 2016a for details).

The examined periods 1983-1986 and 1994-2007 had some limitations in terms of data quality: the satellite image mosaic for 1983 had coarser spatial resolution than had other images (60 vs. $30 \mathrm{~m}$ ), and the period 1994-2007 was long compared to other periods.

For each examined year, individual classified images were combined into one raster mosaic covering the whole study area. To remove lakes from the data, the mosaics were first converted to polygon data. Lakes were removed by filtering out all polygons not connected to the main channel polygon. All remaining lakes were manually removed. Because clouds created gaps in the channel network, some detached parts of the network were manually included in the final channel network product. The final channel network in vector format was used for channel planform analysis. It was backtransformed to raster data (with original cell size) for analysis of accumulation and erosion. The Mackenzie Delta was visited in August 2014 to improve the understanding of the channel processes on-site. Visited sites and photographs were positioned with handheld GPS.

TABLE 1 Landsat images used to create the six mosaics and corresponding hydrological conditions

\begin{tabular}{|c|c|c|c|c|c|c|}
\hline Year & $\begin{array}{l}\text { Number of } \\
\text { images }\end{array}$ & Type & Image dates & $\begin{array}{l}\text { Spatial resolution/ } \\
\text { instrument }\end{array}$ & Discharge $\left(\mathrm{m}^{3} / \mathrm{s}\right)$ & $\begin{array}{l}\text { Water level Mackenzie } \\
\text { River }(\mathrm{m})\end{array}$ \\
\hline 1983 & 4 & Raw & July 7, 9, 3 & 60/MSS & $11,900-15,000$ & $4.5-5.0$ \\
\hline 1986 & 6 & Preclass. & August 8 and 10, September 11 & $30 / \mathrm{TM}$ & $11,200-17,200$ & $4.4-5.6$ \\
\hline 1994 & 8 & Preclass. & July $15,22,27$, and 31 ; August 7 & $30 / \mathrm{TM}$ & $12,800-17,300$ & $4.4-5.4$ \\
\hline 2007 & 3 & Preclass. & August 27 and September 3 & $30 / \mathrm{TM}$ & $12,400-13,600$ & $4.3-4.6$ \\
\hline 2011 & 7 & Preclass. & July 14 and 28; August 4, 8, 29, and 31 & $30 / \mathrm{TM}$ & $13,700-17,100$ & $4.7-5.5$ \\
\hline
\end{tabular}

Note. Several images were needed to cover the entire Mackenzie Delta. The 1983 mosaic was created from raw Landsat images, classified by us, while preclassified surface water products were available for other years (Landsat Surface Reflectance Climate Data Record, U.S. Geological Survey, 2016a, 2016b). Due to cloudiness and other disturbances, images from different days were used in the mosaics. However, the discharge and water level conditions during the images were comparable at "Mackenzie River at Arctic Red River" gauging station (Figure 1; Hydrological data: HYDAT Database, Water Survey of Canada). 


\subsection{Analysis of accumulation and erosion}

The amount of land surface accumulation and erosion between each five pairs of examined years (1983-1986, 1986-1994, 1994-2007, 2007-2011, and 2011-2013) was analysed as the amount of pixels that changed from (a) water to dry land (land surface accumulation) or (b) dry land to water (land surface erosion; Figure 3). Because all water pixels of the channel network mosaics had a cell value of 1 and all dry land pixels a cell value 0 , accumulation and erosion could be calculated with basic raster overlay analysis (using ArcGIS 10.3.1 Raster Calculator; ESRI, 2016). Lakes were treated as dry land in all analyses. Because the 1983 mosaic had a 60-m resolution (Table 1), it was compared to the 1986 mosaic that had been resampled to the corresponding spatial resolution.

\subsection{Analysis of channel planform change}

The entire channel network of the delta plain was analysed in vector format to examine changes in (a) channel width and (b) direction of the main flow path centreline, hereafter referred to as "flow direction," and (c) the lateral migration of the channels. Moreover, changes in (d) sinuosity and (e) braiding of six main channels were quantified. These five channel variables were analysed at systematic 1-km intervals along the channels. The analysis resulted in 1,300 complete observations of channel width, flow direction, and channel midpoint position across six examined years (1983, 1986, 1994, 2007, 2011, and 2013). Changes were then calculated between years, and the cumulative change of the channel from 1983 to 2013 was calculated, taking all consecutive years into account. In addition to absolute change patterns, we analysed the patterns of channel width change, flow direction change, and lateral migration in relation to channel size.

For vector analysis, the flow paths (channel centrelines) of each examined year were first determined by applying a "thinning" method to the raster channel network (Figure 4a; Karathanassi, lossifidis, \& Rokos, 1999; Zhan, 1993). Thinning reduced the width of linear raster cell areas with the same cell value to narrow (one-cell-wide) paths. The paths were then converted to polyline features, and the resulting channel network was manually checked and corrected. Only the main flow paths were included in the final channel network, whereas all flow paths of the six main channels were used for quantifying braiding.

The raster to vector conversion resulted in flow paths with unrealistically sharp turns (Figure 4b). The flow path polylines were simplified with a Snakes method for line smoothing (Burghardt, 2005; Figure 4b) to reduce unrealistic flow directions. Snakes method is an energy minimisation method and effectively smooths the sharp turns of a polyline while preserving its general shape (Burghardt, 2005). The relatively conservative default parameter values were used (Snakes alpha parameter $=1$ and beta parameter $=1$; both options range from 0 to 5 with larger values resulting in smoother lines), and the correctness of the generalisation was visually checked against raw flow paths and raw satellite images.

We quantified the amount of change caused by Snakes smoothing on the flow paths by sampling the difference between unsmoothed and smoothed lines. The 2013 channel flow paths were sampled at channel cross sections ( $n=2,696$ ). The average difference between unsmoothed and smoothed flow paths was $8.18 \mathrm{~m}$ (median $6.14 \mathrm{~m}$ ). This is less than the pixel size of the Landsat data (30-60 m), which represent the narrowest channels taken into consideration in this study. Thus, smoothing did not essentially alter the data and enables the calculation of meaningful flow directions.

The 2013 channel network was used as a reference for all other years. It was therefore manually checked and edited to make sure that each channel segment (from one braining point to another) consisted of one separate polyline with a unique identifier code. A perpendicular sampling line was automatically created at 1-km intervals along the 2013 channel network (Figure 4c). The length of the sampling line was set proportional to the channel width, to accommodate channel changes between examined years. The sampling lines were manually checked. They created an irregular sampling grid with $\sim 2,700$ lines (Figure 4c), each having a unique identifier code.

The polygon layers representing the channel network in each examined year were sampled using the sampling grid: Channel cross sections were created for each year by intersecting the water polygon features with the grid. The number of cross sections $(1,800-2,700)$

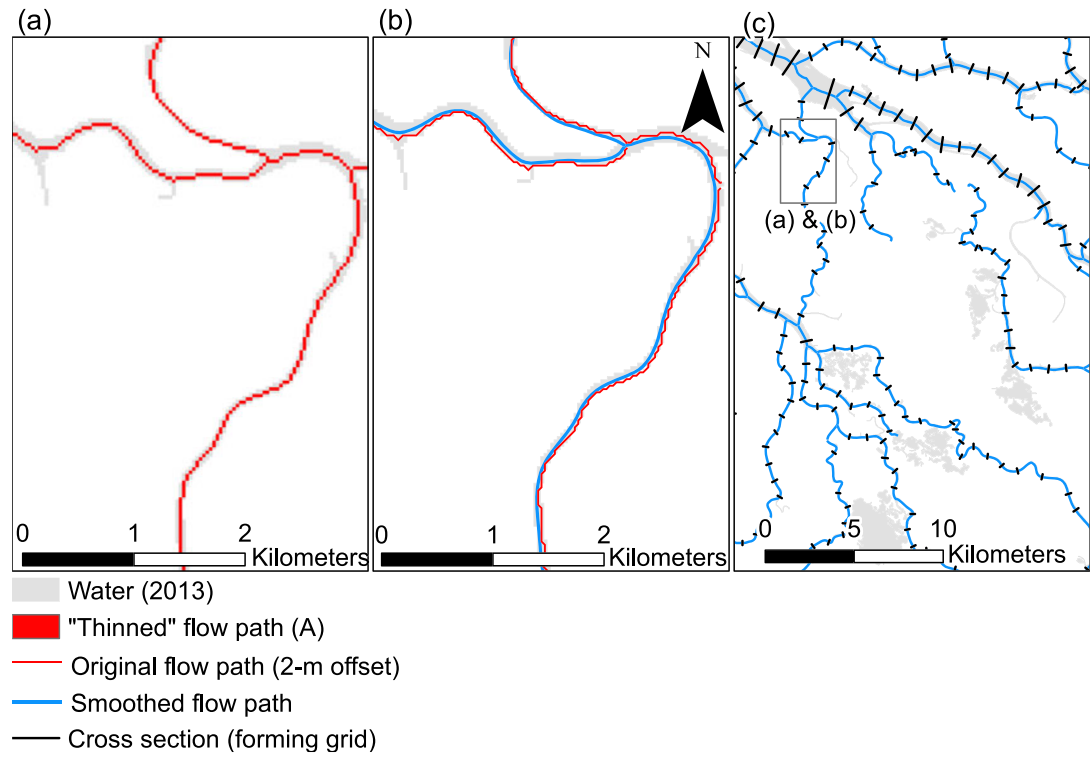

FIGURE 4 Production of the main flow path polylines from raster data and the sampling grid. (a) The classified raster data are first "thinned" (Karathanassi et al., 1999; Zhan, 1993) to reduce the width of linear raster cell areas to one-cell-wide paths. (b) The thinned flow path is converted into a polyline and smoothed with the Snakes method (Burghardt, 2005) to reduce artificial sharp turns while retaining the general shape of the line. (c) For sampling the channel network, a grid of cross sections (perpendicular to the main flow path) is created at 1-km intervals along the 2013 channels. This sampling grid is used for sampling all 6 years of channel data 
mainly depended on the quality of the satellite image mosaic for each year. Each cross section could be matched to that of other years using the unique identifier code, inherited from the grid.

Three channel variables were calculated for each cross section, separately for each year. (a) Channel width was calculated as the length of the cross section. (b) Flow direction was quantified as the bearing of the main flow path centreline. It was calculated for an individual linear segment of the flow path network that intersected a cross section. The bearing of the segment was calculated with trigonometry from its endpoint coordinates. This method is sensitive to the direction of the polyline objects, which is randomly determined when using automatic raster to polyline conversion: Thus, the flow direction values were checked and corrected if they were opposite to the actual direction of flow. (c) Channel midpoint coordinates ( $x$ and $y$ ) were calculated for the midpoint of each cross section.

The change from one examined year to the next was calculated for the three channel variables. The absolute change in channel width and flow direction (irrespective of the direction of change) was used for all further analyses, because we were interested in the amount of change. Lateral migration between 2 years was calculated from the midpoint coordinates of the channel cross section with the Pythagorean equation:

$$
\text { Migration between years } A \text { and } B=\sqrt{\left((x B-x A)^{2}+(y B-y A) 2\right)} \text {, }
$$

where $x B$ and $x A$ are the $x$ coordinates in years $B$ and $A$, respectively; and $y B$ and $y A$ are the corresponding $y$ coordinates. In addition, the cumulative change over the 30 -year period was calculated for all three variables ([1983 to 1986] + [1986 to 1994] + [1994 to 2007] + [2007 to 2011 ] + [2011 to 2013]). The cumulative change values were used for all analyses of the spatial patterns of delta planform evolution.

The significance of change between examined years across the entire delta plain was analysed with pairwise Student's $t$ test with confidence level of $95 \%$. The results indicated whether the channel width, flow direction, or channel midpoint position changed significantly during the examined period, when looking at the delta plain as a whole.

Areas of particularly large changes were identified with an outlier test. Outliers were identified by calculating normal scores (or $Z$ scores; differences between the cross section value and the mean of all cross sections divided by the standard deviation; Schiffler, 1988) and associated $p$ values at the $95 \%$ confidence level. For each period, the test identified cross sections that significantly differed from the majority of cross sections. All identified outliers had experienced significantly larger changes than had the average cross section. Separately for each examined variable, we calculated the number of periods when the cross section was classified as an outlier. This total number of outliers was used to identify cross sections with recurrent large changes in channel width, flow direction, and position.

Changes were averaged over the six main channels to analyse potential channel-specific processes. These six channels are the widest and longest in the delta and the main collector channels in different parts of the study area (Figure 1). Moreover, sinuosity and braiding indices were calculated for each main channel for the six examined years. The sinuosity index value was calculated by dividing the main flow path length by the straight downvalley length (Friend \& Sinha, 1993). The braiding index value was calculated by dividing the sum of lengths of all flow paths by the length of the main flow path (Richards, 1982). Moreover, the six main channels were cut into shorter segments to analyse variation along the channels. The channels were cut at main bifurcation points to account for the major changes in the downstream channel flow and morphology, caused by tributaries. These main channel segments are introduced in Figure S2. Changes in channel planform variables were averaged over these main channel segments.

The analyses were undertaken in QGIS (version 2.12.0; QGIS Development Team, 2016), ArcGIS (10.3.1; ESRI, 2016), and R (3.2.3; R Development Core Team, 2016). Spatial Analyst's Thin tool was used for thinning rasterised linear features (ESRI, 2016). Snakes method was implemented with GRASS v.generalize algorithm (Bundala, Bergenheim, \& Metz, 2015), and vectorisation with GDAL Polygonize (raster to vector) algorithm (GDAL, s.a., 2016); the sampling grid was created with QGIS (2016) Station Lines plugin (version 0.1.2; Bartoletti, 2014) and cross section midpoints with GDAL/OGR Create points along lines algorithm (QGIS, s.a.). Statistical analyses were conducted with the $\mathrm{R}$ base package tools and the R package outliers (version 0.14; Komsta, 2011).

\section{4 | RESULTS}

\subsection{Temporal patterns in channel planform evolution}

The amount of accumulated and eroded land surface was in balance in the delta plain during the last 30 years (Figure 5a). Over the entire study period of 30 years (1983-2013), a total of $\sim 900 \mathrm{~km}^{2}$ of new land surface accumulated in the Mackenzie Delta (Figure 5a). Similarly, $900 \mathrm{~km}^{2}$ of land surface was eroded (Figure 5a). Both surface accumulation and erosion rates were thus $30 \mathrm{~km}^{2}$ per year.

The results indicate that the cumulative change in channel width over the examined 30 years was $200 \mathrm{~m}$ (7.2 m/year; Figure 5b), when averaged over the entire delta plain. Flow direction also changed considerably, by $20^{\circ}\left(0.8^{\circ}\right.$ /year), and the channels migrated laterally a total of $90 \mathrm{~m}$ (3.1 m/year; Figure 5b) on average. These cumulative values are nondirectional, that is, not differentiating between widening and narrowing of the channels, clockwise and anticlockwise changes in flow direction, or migration to different directions.

In general, increasing length of the examined period increased the amount of detected delta plain changes. However, there was considerable variation in the annual rates of change: On the basis of rates of surface accumulation and erosion and all three channel variables, the delta plain was most dynamic at the beginning and at the end of the examined 30-year period (Figures 6 and 7). Land surface erosion dominated over accumulation at the beginning and at the end of the period (Figure 6). The largest yearly changes occurred between 1983 and 1986, whereas the delta plain remained most stable between 1994 and 2007 (Figure 6). This pattern was evident also when examining all six main channels individually (Figure 7a-c). The first half 
(a)

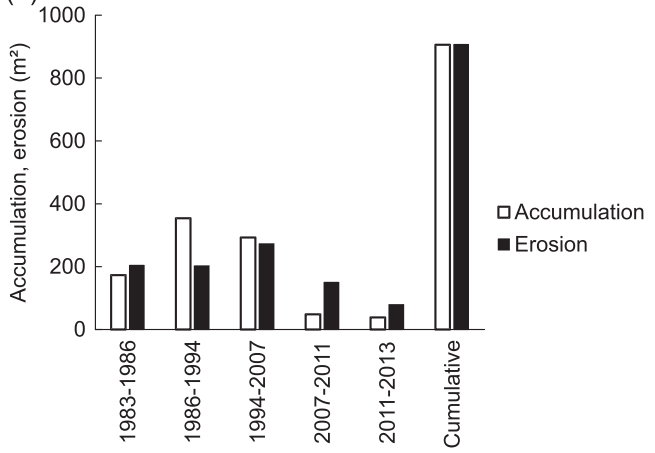

(b)

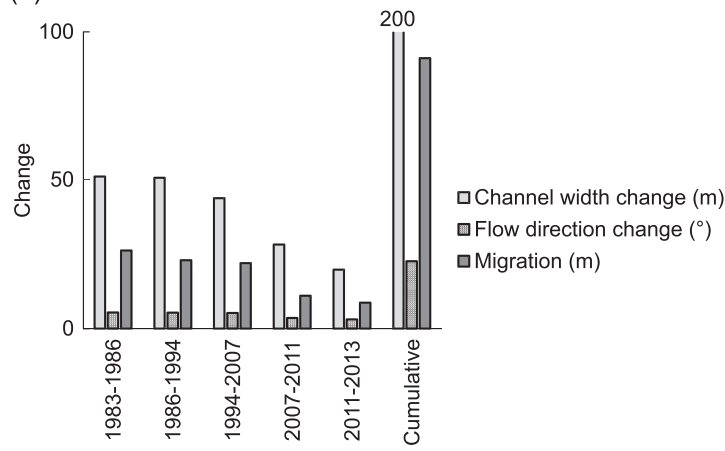

FIGURE 5 (a) Total area of accumulated and eroded land surface during each examined period and (b) total change in planform variables between consecutive years, averaged over all cross sections of the Mackenzie Delta

(a)

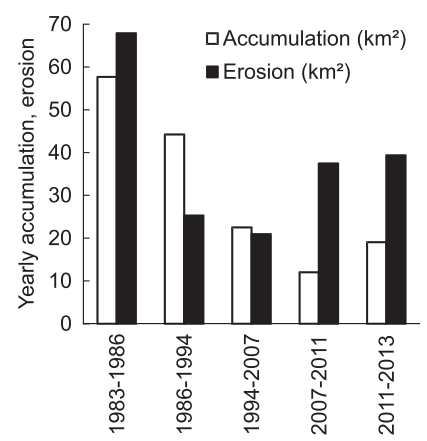

(b)

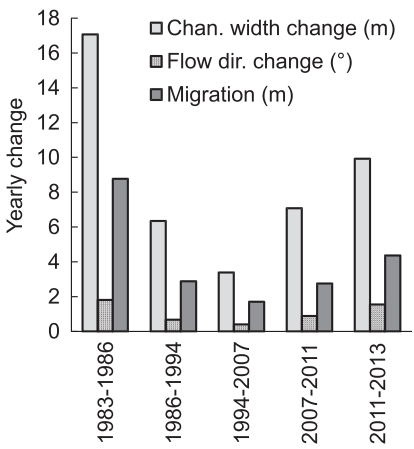

(c)

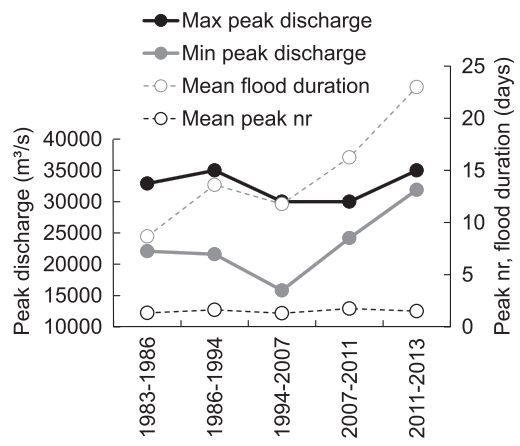

FIGURE 6 Temporal patterns in yearly rates of (a) surface accumulation and erosion, and (b) channel width change, flow direction change, and channel migration and (c) in the Mackenzie River discharge peaks during the 30-year period. Values in (b) are averaged over cross sections of the entire Mackenzie Delta (hydrological data: HYDAT Database, Water Survey of Canada)

of the examined period was mainly characterised by narrowing of the main channels (except for East and West Channels), whereas widening of the channels dominated during the second half (Figure 7a). Examining shorter segments of the main channels individually revealed some smaller scale variation in these patterns, however (Figure S2). For example, the lower parts of the East Channel were highly dynamic also during 2007-2011. Temporal patterns of channel width change along the lower parts of West Channel were opposite to the general trends, reaching the minimum during 1983-1986 and maximum during 2007-2011 (Figure S2).

On the basis of Student's $t$ tests, channel width changed significantly at the beginning and at the end of the examined 30-year period and remained stable between 1994 and 2007 (Table 2). There was no significant change in flow direction between consecutive years (Table 2). The results indicate that the channels migrated significantly between 1983 and 1986 (in the east-west direction) and again between 1994 and 2007 (in both east-west and north-south directions; Table 2). The results thus suggest that between 1994 and 2007, the delta plain experienced major migration of channels, but it did not significantly affect their width or flow direction.

There were only minor changes in the sinuosity of the six main channels, and no common trends towards more sinuous or straighter channels could be detected (Figure 7d). In general, sinuosity of the channels slightly increased during 1983-1994 and decreased during 1994-2013, except for West Channel that had a small decreasing trend (Figure 7d). Braiding of the main channels evolved more but showed no clear trends or common patterns: For example, whereas braiding of the Napoiak Channel increased, that of Peel River decreased during 1983-2013 (Figure 7e). In general, the largest changes in sinuosity and braiding occurred at the beginning (1983-1986) and at the end (2011-2013) of the period, but differences in individual channels were large (Figure 7d,e).

\section{2 | Hydrology and planform change}

Details of the flooding regime of the Mackenzie River in 1983-2013 are presented in Table S1. During 1983-2013, the annual peak discharge of the Mackenzie River at the entrance of the delta varied between 15,800 and $35,000 \mathrm{~m}^{3} / \mathrm{s}$ (average annual peak discharge $27,800 \mathrm{~m}^{3} / \mathrm{s}$ ) while winter low discharge was in the range of 2,060$4,090 \mathrm{~m}^{3} / \mathrm{s}$ (Figure 8). There were major differences between hydrological years (September-August) in the number and magnitude of flood peaks and in the number of flood days (Figure 8). Hydrological years 1983-1984, 1986-1987, 1994-1995, and 1999-2000 were low-discharge years in all aspects: There were no flood peaks, and mean discharge was lower than average. Year 1991-1992 was the high-discharge year in terms of spring peak magnitude and flood duration. There were also a number of other peak years when evaluated on the basis of different aspects of the flooding: years with single short but high flood peaks (e.g., 2012-2013), years with several flood peaks of short duration (e.g., 1990-1991), and years with several long but low flood peaks (e.g., 2008-2009). 


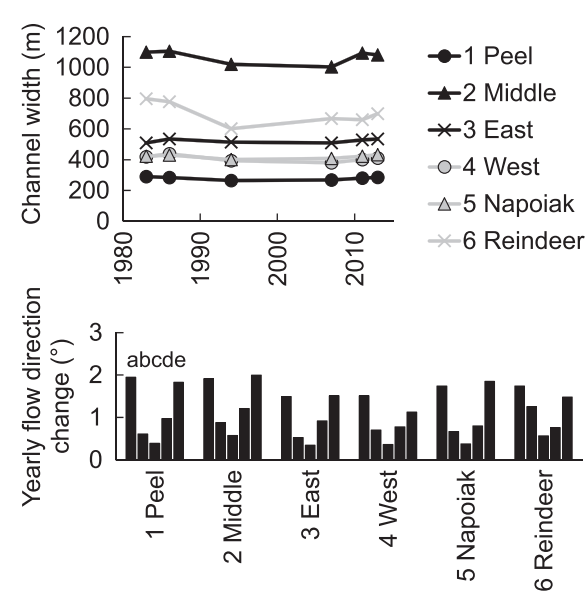

(a)

(b)
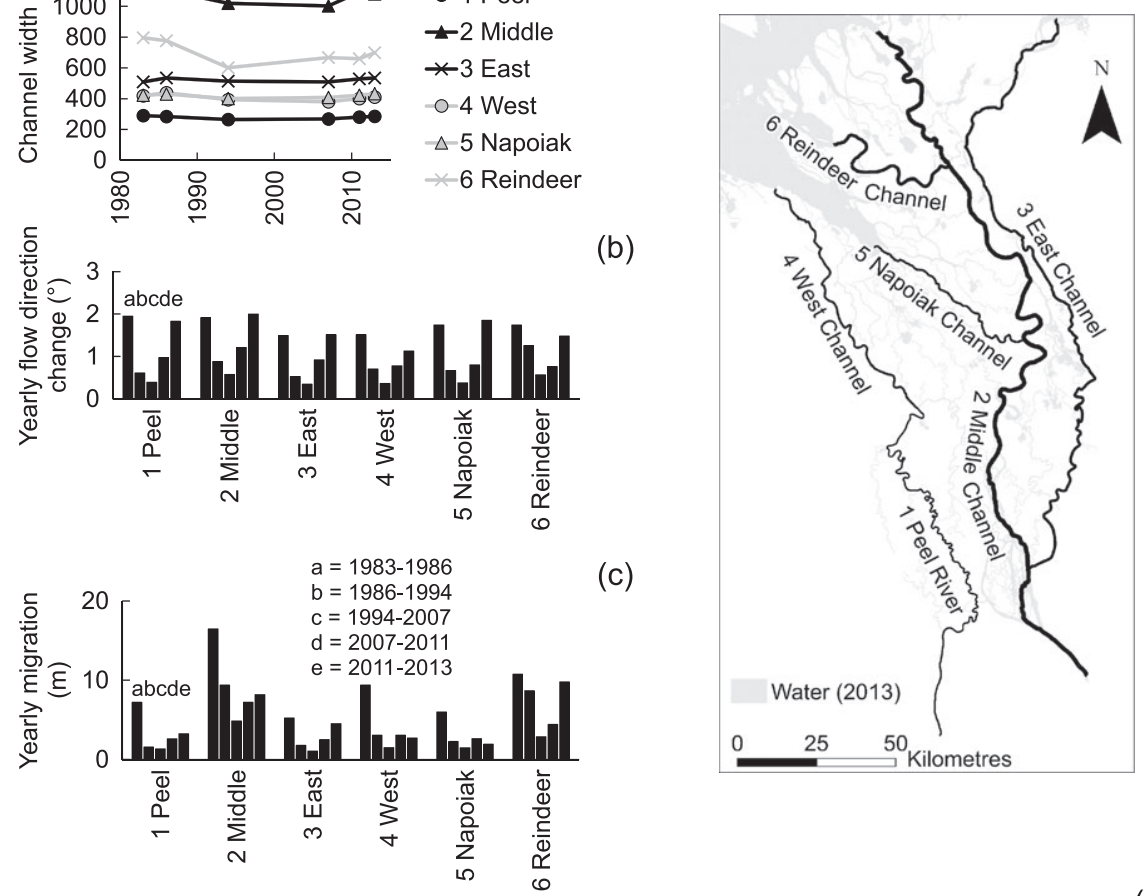

(c)

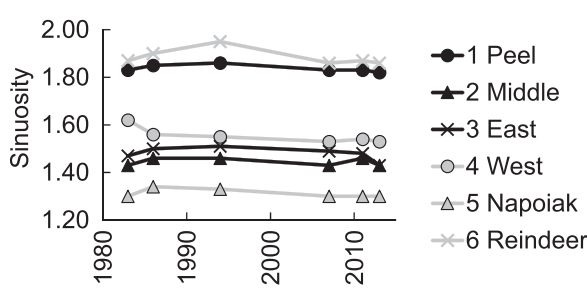

(d)

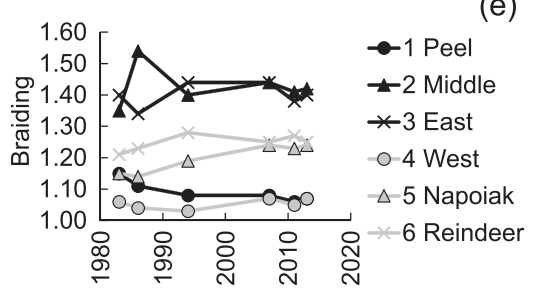

FIGURE 7 Difference between the six main channels in the temporal variation of average (a) channel width, (b) yearly change in flow direction, (c) yearly migration, (d) sinuosity, and (e) braiding. Values are averaged over all cross sections along each main channel

TABLE 2 Statistics for paired Student's $t$ tests ( $t$ statistic and the associated $p$ value), evaluating the difference between 2 years (From and To) in channel width (Width), flow direction (Flow dir.), and lateral migration in the east-west (Migration $x$ ) and north-south (Migration $y$ ) directions

\begin{tabular}{|c|c|c|c|c|c|c|c|c|c|c|}
\hline \multirow[b]{2}{*}{ From } & \multirow[b]{2}{*}{ To } & \multirow[b]{2}{*}{ Years } & \multicolumn{2}{|l|}{ Width } & \multicolumn{2}{|c|}{ Flow dir. } & \multicolumn{2}{|c|}{ Migration (x) } & \multicolumn{2}{|c|}{ Migration $(y)$} \\
\hline & & & $\bar{t}$ & $p$ & $\bar{t}$ & $p$ & $\bar{t}$ & $p$ & $\bar{t}$ & $p$ \\
\hline 1983 & 1986 & 3 & 2.69 & 0.007 & -0.80 & 0.421 & 3.70 & $<0.001$ & 0.42 & 0.676 \\
\hline 1994 & 2007 & 13 & -0.72 & 0.469 & -0.93 & 0.350 & 2.00 & 0.045 & 4.19 & $>0.001$ \\
\hline 2007 & 2011 & 4 & 4.67 & $<0.001$ & 0.56 & 0.575 & -0.92 & 0.359 & 1.84 & 0.065 \\
\hline
\end{tabular}

Note. Significant $p$ values at the $95 \%$ confidence level are highlighted.

The hydrological time series showed negligible positive trends in the minimum, mean, and maximum annual discharge during the 30-year period but considerable variation in the annual maximum discharges (Figure 8a). Maximum flood peaks were generally the highest at the beginning (1983-1993) and at the end of the period (2011-2013), whereas the highest flood peaks were generally absent during 1993-2011 (Figure 8a). However during the 1993-2011 period, there were also larger than 1-year floods (25 flood peaks and 221 days of flood). Moreover, snowmelt and ice breakup floods in spring occurred annually from 2001 onwards after a few gap years in 1983-2000. The number of flood peaks and flood days exhibited slightly different patterns: Periods 1987-1993 and 2004-2009 were dominated by multiple annual flood peaks and longest flood duration (Figure 8b).

The high maximum discharge periods 1983-1986 and 2011-2013 were characterised by large delta planform changes and straightening of the main channels (Figures $6 \mathrm{~b}$ and $7 \mathrm{~d}$ ), whereas the low-peak period 1994-2007 was coupled with small changes and increased sinuosity (Figures 6b and 7d). Although 1986-1994 was a high-flood period in all aspects except mean flood duration, the delta planform changes remained subtle (Figure 6b). During the peak change periods, flooding lasted long in 2011-2013 but not in 1983-1986 (Figure 6b). The last 
(a)

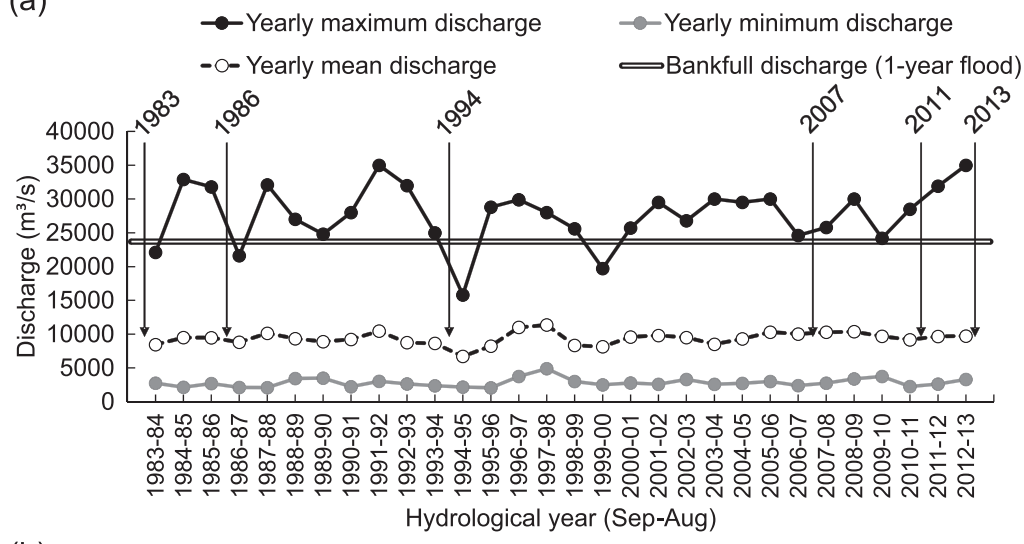

(b)

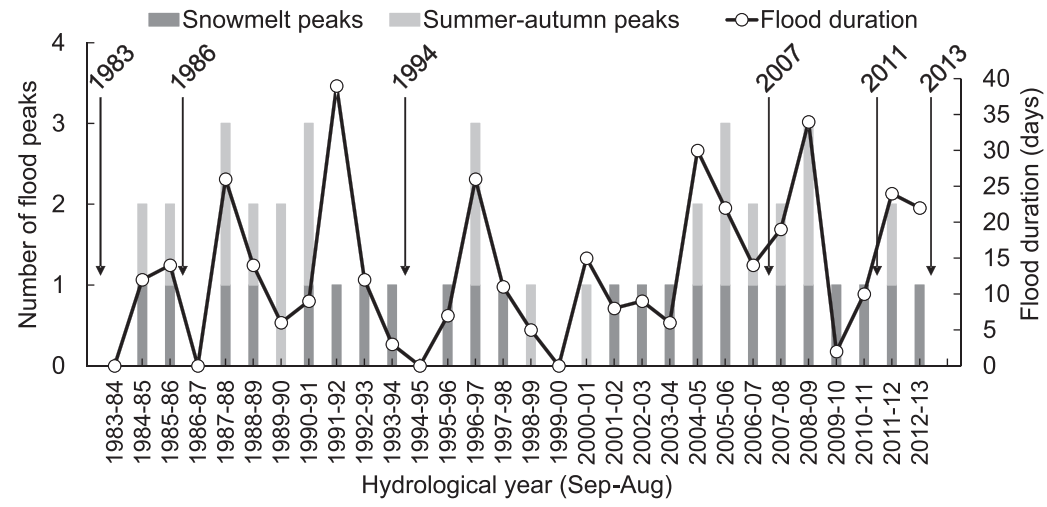

FIGURE 8 (a) Year-to-year variation in annual maximum, mean and minimum discharge, and (b) number of flood discharge peaks (associated with either melting snow in spring or high rainfall in summer and autumn) and flood duration (total number of days with discharge higher than 1-year flood discharge) at "Mackenzie River at Arctic Red River" gauging station (Figure 1). Statistics are presented for hydrological years, from September to August, which approximately represent full years between satellite image mosaics. Examined satellite data are marked with arrows (data: HYDAT Database, Water Survey of Canada) two periods witnessed annual flooding unlike the first three periods, and the mean number of flood days was relatively high during the intermediate-change period 2007-2011 (Figure 6b). Moreover, the period 1994-2007 with slow changes in the delta plain was characterised by a large proportion of years lacking snowmelt and ice breakup floods and therefore lack of extreme water levels caused by ice jams (Figure 8b). Thus, the results indicate that primarily high maximum discharge and secondarily long annual flood duration are associated with large changes in the delta planform.

The effect of one spring flood on the delta planform could not be conclusively deduced from the data. However, the change between 2011 and 2013 was mainly attributable to two shorter floods in 2012 and one large spring flood in May 2013 (Figure 8; lasting in total 24 and 22 days with maximum discharge of 32,000 and $35,000 \mathrm{~m}^{3} / \mathrm{s}$ in 2012 and 2013, respectively). It could be estimated that the long 2013 flood event resulted in half of the 2011-2013 change, that is, surface accumulation of $20 \mathrm{~km}^{2}$ and erosion of $40 \mathrm{~km}^{2}$ across the entire delta. The flood changed (mainly increased) the width of the channels by $10 \mathrm{~m}$ and their flow direction by $1.5^{\circ}$ and caused them to migrate laterally by $4.5 \mathrm{~m}$ when averaged over the Mackenzie Delta.

\section{3 | Spatial hotspots of change}

Spatially, the accumulation and erosion processes were far from uniform across the delta plain (Figure 9). The largest changes occurred along the widest channels and along the lower parts of the delta (Figure 9a). The complex anastomosing and braiding upper parts of the Middle Channel were the hotspot of change (Figure 9b). At a finer spatial scale, land surface accumulation took place in point bars of the inner banks whereas surface erosion dominated in the outer banks of the meander bends (Figure 9c).

Analyses of absolute channel planform change and change relative to channel size highlighted different patterns. The largest changes in channel width along the Middle Channel and the lower delta plain reached approximately 3,000 $\mathrm{m}$ (Figure 10a). The outlier analyses confirmed that many channel cross sections in these areas repeatedly underwent exceptionally large changes ("Hotspots of change" in Figure 10a, Figure S2). However, examination of the amount of change in channel width in proportion to the size of the channel revealed the dynamic nature of some smaller channels (Figure 10b). In particular, there were two smaller but highly dynamic meandering channels in the middle part of the eastern delta plain (upper East Channel being one of them; Figure 10b).

The largest cumulative changes in flow direction over 30 years were as high as $140^{\circ}$ (Figure 10c). The main flow path turned most along the largest channels and in the lower delta plain, and also cross sections frequently experiencing large flow direction changes were located here (Figure 10c). Relative to their size, however, smaller channels all over the delta plain appeared more dynamic than did the larger ones (e.g., Peel River and upper East Channel; Figure 10d).

The largest lateral migration of the channels of almost up to 1,444 m was again detected along the largest channels (Figure 10e). Outlier cross sections with repeated exceptionally large migration were also found in these areas (Figure 10e). In proportion to channel width, the amount of cumulative lateral migration was relatively uniform across the delta plain (Figure 10f).

Overall, all three channel variables detected similar spatial patterns in channel planform change, when relating the amount of change to 
(a)

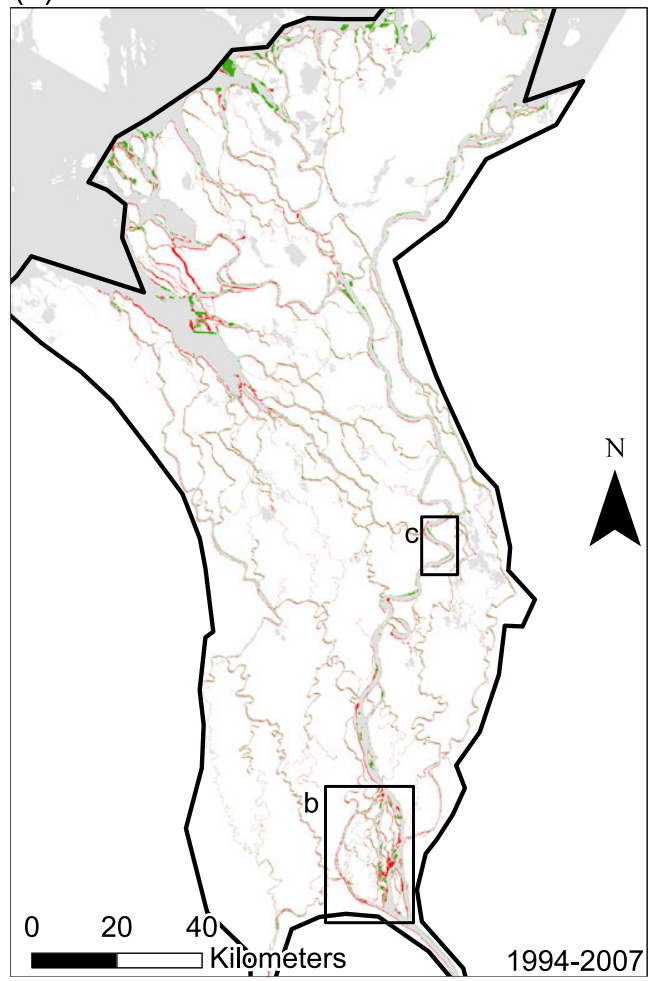

(b)

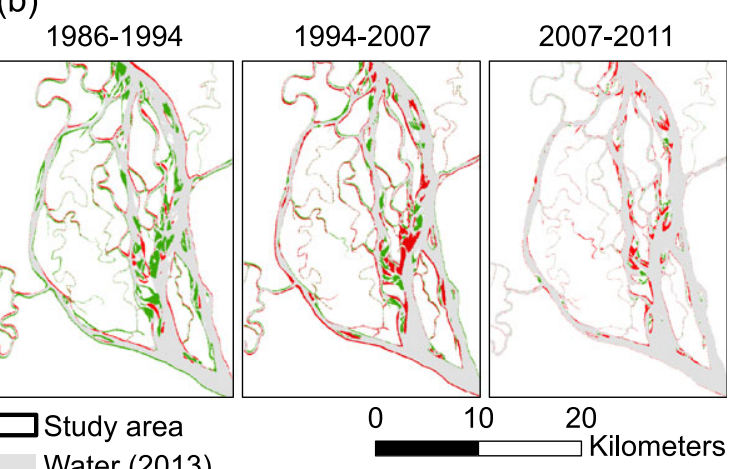

Water (2013)

Accumulation

Erosion

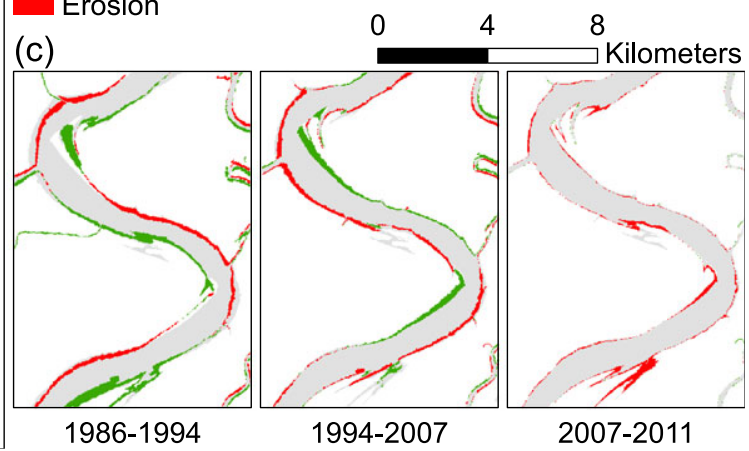

FIGURE 9 (a) Accumulation and erosion between 1994 and 2007 across the entire delta plain. (b) An example of complex accumulation and erosion patterns in an anastomosing channel section (with sandy bedforms, more stabilised islands, and lateral accretion surfaces) of the upper Middle Channel during three periods. (c) An example of meander bend evolution with characteristic accumulation along inner banks and erosion along outer banks in Middle Channel during the same three periods
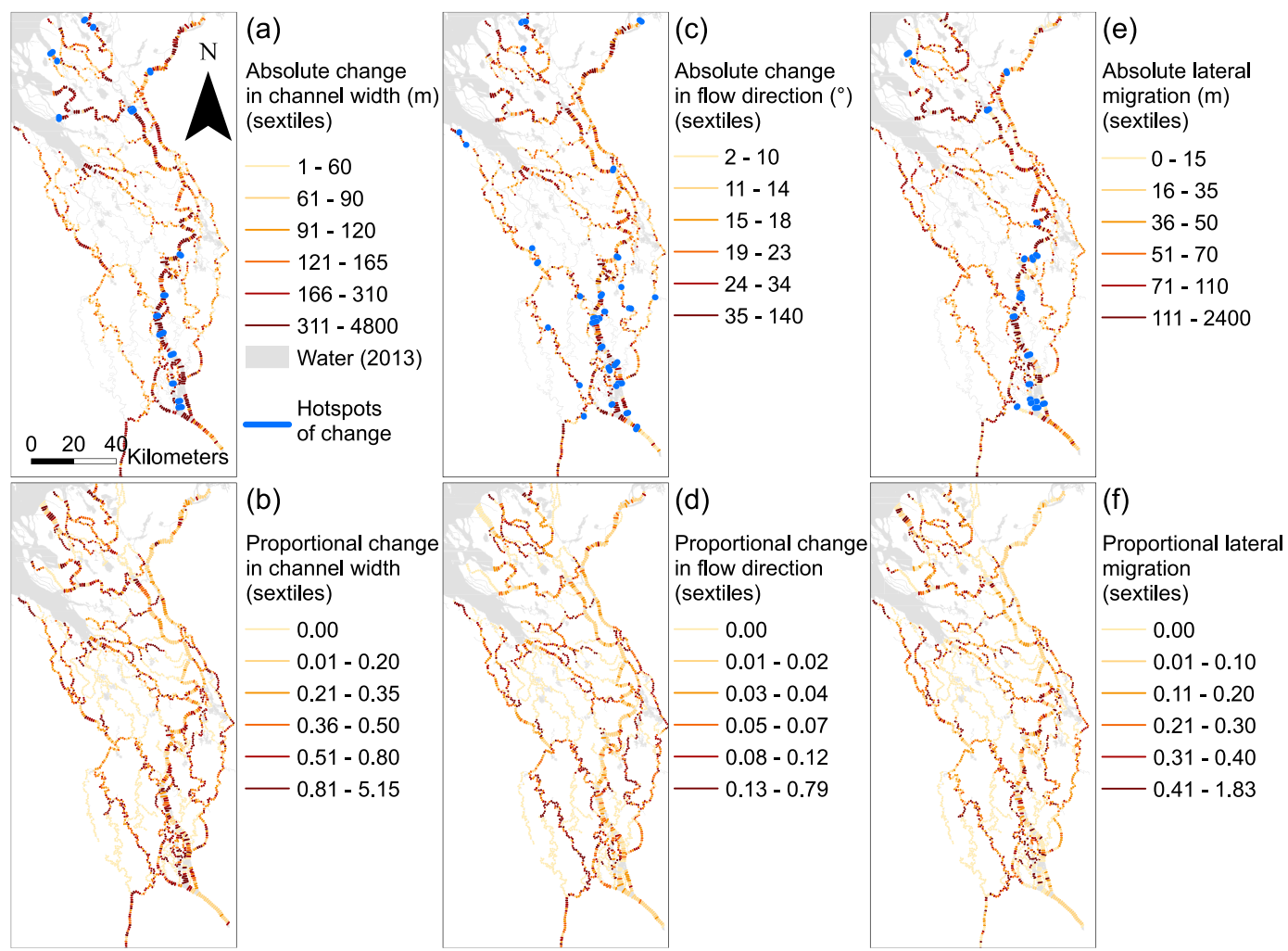

FIGURE 10 Cumulative change in channel (a-b) main flow path width, (c-d) flow direction, and (e-f) lateral migration during $1983-2013$. Cumulative change (upper panels) is the sum of absolute change values (irrespective of direction) over five consecutive periods (1983-1986, 1986-1994, 1994-2007, 2007-2011, and 2011-2013). Proportional cumulative change (lower panels) accounts for the size of the channel and was calculated by dividing the cumulative change by the average width of the channel in 2013. "Hotspots of change" are those channel cross sections that were identified as outliers during at least three examined periods and thus repeatedly experienced exceptionally large changes 
channel size. Both large and small channels experienced large changes. In proportion to their size, there were four areas that remained relatively stable throughout the examined 30 years: straight parts of the Middle Channel (Figure 10), the lower East Channel, and the area where Peel River meets West Channel (Figure 10).

When examining the six main channels separately, we found that the largest absolute yearly changes during 1983-2013 in channel width, flow direction, migration, and braiding occurred in the Middle Channel (the main collector channel of the delta; Figure 11; Table 3 ; Figure S2). Flow direction varied almost equally as much in the highly sinuous Peel River, and sinuosity of the (intermediately sinuous) East Channel changed most (Figure 11; Table 3). When examining all five variables, the wide Reindeer Channel in the lower delta was on average the second most dynamic channel (Figure 11; Table 3; Figure S2). Overall, flow direction change was the most uniformly distributed and braiding change the most unequally distributed channel variable (Figure 11).

\section{5 | DISCUSSION}

This paper presents large-scale patterns of planform evolution of the Mackenzie Delta in the Arctic Canada over the past 30 years and suggests how the evolution is driven by flooding. In addition, it introduces a useful remote sensing-based methodology for mapping Arctic riverine evolution of a large remote area.

Our results indicate that the channel network of the Mackenzie Delta has evolved constantly, though with highly varying rate, over the past 30 years. The in-channel accumulation and erosion of land surface have been in balance in the delta plain. This is in line with some previous studies (Carson et al., 1999), whereas positive net sediment load and point measurements of accumulation and erosion have suggested a dominance of accumulation during the early part of the studied period (reviewed by Carson et al., 1999). However, much of the net sedimentation in the delta is attributable to overbank and lake sedimentation (Carson et al., 1999), which were not considered in this paper. In addition, many of the most rapid changes in channel morphology occur in the outermost delta, some of them beyond the network considered in this paper (e.g., Jenner \& Hill, 1998; Solomon et al., 2008). The delta plain was most dynamic at the beginning and at the end of the examined period (1983-2013).
In-stream land surface accumulation and erosion led to changes in the width, flow direction, and braiding of the channels and caused the channels to migrate. In response to meandering processes, the sinuosity of the channels changed, most rapidly at the beginning and at the end of the 30-year period.

Climate change is expected to have a large effect on discharge conditions, permafrost, and, consequently, channel evolution in the Arctic (Palmer et al., 2008; Schuur et al., 2008; Walker, 1999). In accordance with previous studies however (Abdul Aziz \& Burn, 2006; Woo \& Thorne, 2003; Yang et al., 2015), our study of the past 30 years in the Mackenzie Delta did not detect any uniform trends in average or peak discharges or the rate of riverine evolution. On the basis of our data for 1983-2013, climate change has not decreased the frequency of snowmelt and ice breakup floods in the Mackenzie Delta, and, unlike previously suggested (cited by Lesack \& Marsh, 2007; Lesack et al., 2013; note however differences in measuring the period), the annual flooding period may not have shortened significantly. Instead, spring floods occurred annually in 2002-2013 and increased in magnitude again at the end of the examined period, contradicting some previous findings (e.g., Yang et al., 2015). For example, according to Yang et al. (2015), the maximum spring discharges have decreased by about $3,000 \mathrm{~m}^{3} / \mathrm{s}$ in 1973-2011 at the Mackenzie River at Arctic Red River station. Moreover, Abdul Aziz and Burn (2006) report a decreasing trend in the late spring and autumn discharges in 1968-2000 at gauging stations of the Mackenzie basin. Lesack et al. (2013) also presented a possible decline in the flood magnitude in the outer delta but, similar to our results, found no trends in the upper and central delta.

We suggest that high and persistent floods drive the rapid evolution of the delta plain. Interannual variation in the magnitude and duration of flood peaks, together with changes in permafrost, are the main factors influencing the rate of channel planform change (cf. Carson et al., 1999; Hooke, 1979). This would indicate that future climate change, particularly snow accumulation and spring melt conditions modified by air and water temperature trends and extremes, will have a dramatic influence on the delta plain (Lesack et al., 2014). Despite the lack of clear trends in the discharge regime during 1983-2013, the flooding of the Mackenzie River has experienced distinct interannual variation, resulting in a clear temporal pattern in the delta plain evolution. Flooding was highly variable but intense during the late 1980 s and early 1990 s, resulting in rapid changes in
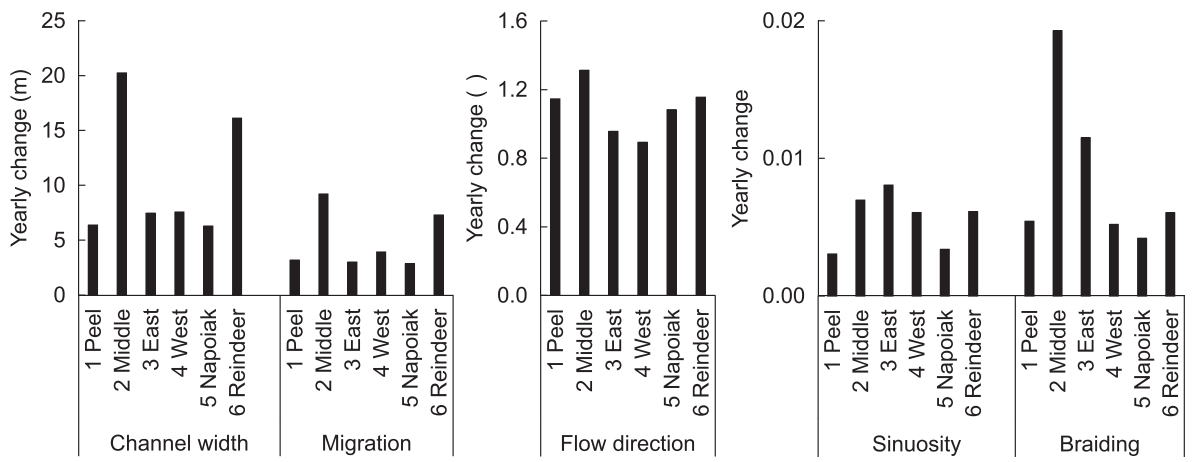

FIGURE 11 Differences between the six main channels (Figure 1) in the average change rate of five channel planform variables. The yearly change rates are averaged over all cross sections along the channel and all examined periods. The values are absolute changes, irrespective of direction 
TABLE 3 Characteristics of the six main channels of the Mackenzie Delta including the length, width, sinuosity, and braiding of the channels

\begin{tabular}{|c|c|c|c|c|c|c|}
\hline Channel name & Length (km) & Min width (m) & Mean width (m) & Max width (m) & Sinuosity & Braiding \\
\hline 1 Peel River & 190 & 100 & 290 & 660 & 1.84 & 1.08 \\
\hline 2 Middle Channel & 310 & 200 & 1,080 & 2,890 & 1.44 & 1.45 \\
\hline 4 West Channel & 110 & 90 & 410 & 1,000 & 1.54 & 1.05 \\
\hline 5 Napoiak Channel & 70 & 120 & 430 & 1,510 & 1.32 & 1.21 \\
\hline
\end{tabular}

Note. The values are based on the Landsat raster mosaic for 2013, converted into vector data as described in Section 3.

the delta plain. The following decade was characterised by less flooding (also reported by Yang et al., 2015) and slower changes in the delta planform. In low-discharge conditions, the sinuosity of the channels increased (cf. Wyzga, 1993). The late 2000s and early 2010s witnessed increasing flood peaks and more frequent and persistent flooding. The increased flooding was accompanied by larger changes in the delta planform. As expected, the sinuosity of the channels decreased in response to flooding, potentially due to meander cut-offs (e.g., Gay, Gay, Martinson, Meade, \& Moody, 1998).

Although this paper concentrates on large-scale patterns of change, local-scale analysis may help in identifying local responses to extreme discharge conditions (Jenner \& Hill, 1998). We acknowledge the importance of spring ice breakup and other local processes in creating localised and short-term variation in the hydrology (Beltaos, 2012; Lesack et al., 2013). Their impacts cannot be accounted for with the procedure described in this study that assumes uniform discharge variability in the delta. To account for these effects, a denser network of gauging station would be needed, potentially combined with field observations and advanced spatial modelling. For example, river ice (floating and bottomfast, flow velocity, and distribution), local temperature conditions (and thermal erosion, influenced by the latitude, Beaufort Sea and microclimatic factors; Burn, 1997), permafrost, sediment properties, sediment budget, sea water level, land use, vegetation establishment (e.g., morphological differences in levees bound by spruces and willows; Beltaos, 2012; Hill et al., 2001), and initial channel network and morphology play a major role in determining changes in the delta planform via influencing the local discharge regime and channel stability (e.g., de Rham et al., 2008; Goulding, Prowse, \& Beltaos, 2009; Goulding, Prowse, \& Bonsal, 2009; Hooke, 2008; Orton $\&$ Reading, 1993; Yang et al., 2015).

We report a rough estimate of the effect of one large spring flood on land surface accumulation and erosion and the width, flow direction, migration, sinuosity, and braiding of channels in the Mackenzie Delta. This information could be used, for example, for estimating the effects of future discharge conditions and discharge regulation on the riverine environment.

As expected, land surface accumulation and erosion in the Mackenzie Delta are localised in strongly anastomosing, braiding (particularly upper Middle Channel; Figure 1), and meandering channels and along the dynamic coastline of the Arctic Ocean (e.g., Jenner \& Hill, 1998; Solomon et al., 2008). In the braiding channels, in-stream sand bars are constantly forming, eroding, and changing shape. A meandering channel gradually erodes its outer cut-banks and forms chute cut-offs whereas point bars develop and grow along the inner banks. As a consequence of accumulation and erosion processes, the width, direction, position, sinuosity, and braiding of the channel change.

Although the absolute changes are most notable along the largest channels (particularly Middle Channel; Carson et al., 1999), small meandering channels may experience relatively rapid evolution as well. For the Middle Channel and the East Channel, our results for lateral migration are in the same range as those of previous studies (Fassnacht $\&$ Conly, 2000). The results suggest that factors other than the size of the channel have a distinct role in determining the dynamic nature of the channel. We hypothesize that majority of the differences between similar-sized channels in the Arctic delta may be due to localised permafrost and increased resistance to geomorphic forces (Cordes et al., 1984; Hill et al., 2001; Syvitski, 1986). Although permafrost is absent beneath most channels and lakes (Smith, 1976), many channel banks are permanently frozen, decreasing their sensitivity to erosion (Nguyen et al., 2009).

Our study demonstrates that Landsat satellite images in combination with continuous hydrological time series provides a useful approach to mapping long-term changes in a large and remote geographical area. The spatial resolution of the data is sufficient for identification of the main landforms of the delta plain (cf. Bryant \& Gilvear, 1999; Henshaw et al., 2013; Petropoulos, Kalivas, Griffiths, \& Dimou, 2015) and coarse enough to be managed with standard PCs and software. Although the original hydrological dataset used in this study was of high quality with only one data gap, simulated hydrological time series would be necessary for selecting remote sensing data and examining hydrological conditions in ungauged watersheds or in watersheds with lower quality time series (Strömqvist et al., 2012).

The main challenge in working with passive satellite data is cloudiness, making majority of the satellite images inadequate for terrestrial mapping. In this study, the period 1994-2007 is very long due to the lack of cloud free mosaics, masking potential year-to-year oscillations in the delta planform. Clouds are also responsible for some misclassified cells, resulting in artificial gaps in the channel network and falsely interpreted erosion or accumulation. The largest errors of this type must be corrected manually while smaller ones remain undetected.

Landsat data are most suitable for large-scale fluvial geomorphological analysis due to the spatial resolution. A higher resolution (and smaller extent) should be preferred when working with smaller landforms and local processes. Our study concentrated on channel evolution, and therefore, lakes were removed from the data first 
automatically and then manually. We found that total accumulation and erosion values were sensitive to manual adjustments (because lakes that unintentionally appear in one raster data result in disproportionate accumulation and erosion values), indicating that results from this type of analysis should be carefully monitored. The coarser spatial resolution of Landsat imagery in 1972-1985 should be considered when building long Landsat time series, and it may have had an effect on the recorded changes between 1983 and 1986 in our study.

This paper also describes how flow paths of a complex delta plain can be successfully determined by applying a "thinning" method (Karathanassi et al., 1999; Zhan, 1993) on classified raster data. In a very complicated channel network, thinning produces a large amount of "noise" or artificial flow paths that need to be manually cleaned. Some more work should be targeted to optimising the processes and reducing the amount of manual cleaning. An automated and systematic sampling design, such as the one used in this article, is useful for quantifying channel properties and their change between examined years. Our sampling grid of channel cross sections at 1-km intervals was quick to establish and enabled the identification of the same channel section in datasets of different years. The concept of cross section sampling is familiar in examining changes in channel geometry over time (Grabowski, Surlan, \& Gurnell, 2014), and the approach described in this paper facilitates its application to a large amount of data. The initial cross section grid required some manual corrections particularly in the braiding channel sections, but once finished, it captured change in channel variables well. One future challenge would be to develop a procedure for identifying in-stream sand bars and track their development and migration over time. Another important task for the future is to quantify the relationship between accumulation and erosion and the flood peak metrics. This would require erosion and accumulation time series with a considerably higher temporal resolution than what was possible in this study but enable forecasting future changes of the delta planform based on climate models (Beighley, Eggert, Wilson, \& Rowland, 2014).

\section{6 | CONCLUSIONS}

This paper describes how Mackenzie Delta in the Arctic Canada has experienced constant evolution with highly varying rate during the past 30 years. Our study demonstrates that the magnitude and duration of flood peaks and the presence of annual spring ice breakup floods determine the rate of Arctic delta planform change. Despite climate change however, no clear trend towards decreased recurrence or magnitude of spring floods (due to decreased snow and ice accumulation in response to climate warming) or increased instability of the delta plain has yet been observed in the Mackenzie Delta. The delta plain was most dynamic at the beginning and at the end of the examined period, corresponding to intense flooding, whereas the rates of change were subtle during the low-flood period 1994-2007. The largest changes have occurred along the wide Middle Channel and along the Arctic Ocean coast. Relative to their size however, smaller meandering channels have been highly dynamic.
We demonstrate the usefulness of passive Landsat satellite data matched with continuous hydrological time series in developing fluvial geomorphological time series of a large and mainly inaccessible area. These open-access data still have some unexploited potential in geomorphological research. With the use of satellite image time series and automated vectorisation and sampling of channels, we foresee advances in fluvial geomorphology resulting from better understanding of processes operating at large spatial and long temporal scales. Moreover, accurate measurements of channel variables are required in hydrological models and efficient procedures for retrieving these variables facilitate the development of hydrological modelling.

\section{ACKNOWLEDGMENTS}

This study was supported by Doctoral programme in Biology, Geography and Geology, University of Turku, the Academy of Finland (RivChange project, Grant 136234), and the Strategic Research Council project, Academy of Finland (COMBAT project, Grant 293389).

\section{ORCID}

Jenni-Mari Vesakoski (D) http://orcid.org/0000-0001-7686-468X

Tua Nylén (10 http://orcid.org/0000-0002-1261-7214

Berit Arheimer (10 http://orcid.org/0000-0001-8314-0735

Markus Holopainen (D) http://orcid.org/0000-0002-6416-2602

Juha Hyyppä (1) http://orcid.org/0000-0001-5360-4017

Petteri Alho (1D http://orcid.org/0000-0001-5252-9609

\section{REFERENCES}

Abdul Aziz, O. I., \& Burn, D. H. (2006). Trends and variability in the hydrological regime of the Mackenzie River basin. Journal of Hydrology, 319, 282-294. https://doi.org/10.1016/j.jhydrol.2005.06.039

Alho, P. (2003). Land cover characteristics in NE Iceland with special reference to jökulhlaup geomorphology. Geografiska Annaler: Series A, Physical Geography, 85, 213-227. https://doi.org/10.1111/j.04353676.2003.00201.x

Alho, P., \& Mäkinen, J. (2010). Hydraulic parameter estimations of a 2D model validated with sedimentological findings in the point bar environment. Hydrological Processes, 24, 2578-2593. https://doi.org/10.1002/ hyp.7671

Bartoletti, L. (2014). QGIS Python Plugin: Station lines. https://plugins.qgis. org/plugins/stationlines/ (7.6.2016)

Beighley, R. E., Eggert, K., Wilson, C. J., \& Rowland, J. C. (2014). A hydrologic routing model suitable for climate-scale simulations of arctic rivers: Application to the Mackenzie River basin. Hydrological Processes, 19, 2751-2768. https://doi.org/10.1002/hyp.10398

Beltaos, S. (2012). Mackenzie Delta flow during spring breakup: Uncertainties and potential improvements. Canadian Journal of Civil Engineering, 39, 579-588. https://doi.org/10.1139/L2012-033

Beylich, A. A. (2008). Mass transfers, sediment budget and relief development in the Latnjavagge catchment, Arctic-oceanic Swedish Lapland. Zeitschrift für Geomorphologie, 52, 149-197. https://doi.org/10.1127/ 0372-8854/2008/0052S1-0149

Brooks, G. R. (2000). Channel changes along the lower reaches of major Mackenzie River tributaries. In: The physical environment of the Mackenzie Valley, Northwest Territories: A base line for the assessment of environmental change (Dyke, L.D. and Brooks, G.R., eds.). Geological Survey of Canada, Bulletin 547, 159-166. https://doi.org/10.1049/ 211926

Bryant, R. G., \& Gilvear, D. J. (1999). Quantifying geomorphic and riparian land cover changes either side of a large flood event using airborne 
remote sensing: River Tay, Scotland. Geomorphology, 29, 307-321. https://doi.org/10.1016/S0169-555X(99)00023-9

Bundala, D., Bergenheim, W., \& Metz, M. (2015). v.generalize-Vector based generalization. https://grass.osgeo.org/grass64/manuals/v.generalize.html (6.6.2016)

Burge, L. M., \& Lapointe, M. F. (2005). Understanding the temporal dynamics of the wandering Renous River, New Brunsvick, Canada. Earth Surface Processes and Landforms, 30, 1227-1250. https://doi. org/10.1002/esp.1196

Burghardt, D. (2005). Controlled line smoothing by snakes. Geolnformatica, 9, 237-252. https://doi.org/10.1007/s10707-005-1283-3

Burn, C. R. (1997). Cryostratigraphy, paleogeography, and climate change during the early Holocene warm interval, western Arctic coast, Canada. Canadian Journal of Earth Sciences, 34, 912-925. https://doi.org/ 10.1139/e17-076

Burn, C. R., \& Kokelj, S. V. (2009). The environment and permafrost of the Mackenzie Delta area. Permafrost and Periglacial Processes, 20, 83-105. https://doi.org/10.1002/ppp.655

Carson, M. A., Conly, F. M., \& Jasper, J. N. (1999). Riverine sediment balance of the Mackenzie Delta, Northwest Territories, Canada. Hydrological Processes, 13, 2499-2518. https://doi.org/10.1002/ (SICI)1099-1085(199911)13:16<2499::AID-HYP937>3.0.CO;2-I

Carson, M. A., Jasper, J. N., \& Conly, F. M. (1998). Magnitude and sources of sediment input to the Mackenzie Delta, Northwest Territories, 1974-94. Arctic 51, 116-124. https://doi.org/10.14430/arctic1053

Chu, Z. X., Sun, X. G., Zhai, S. K., \& Xu, K. H. (2006). Changing pattern of accretion/erosion of the modern Yellow River (Huanghe) subaerial delta, China: Based on remote sensing images. Marine Geology, 227, 13-30. https://doi.org/10.1016/j.margeo.2005.11.013

Cordes, L. D., McLennan, D., \& Pearce, G. M. (1984). Alluvial ecosystems of Mackenzie delta, NWT (Vol. 2). Vancover, BC: Contract report. L.D. Gordes and Assiciates for BC Hydro.

Dalrymple, T. (1960). Flood-frequency analyses, manual of hydrology: Part 3. $80 \mathrm{p}$. Water supply paper $1543-\mathrm{A}$.

Davies, K. F. (1975). Mackenzie River input to the Beaufort Sea. Technical report 15, Beaufort Sea Project.

de Rham, L. P., Prowse, T. D., Beltaos, S., \& Lacroix, M. P. (2008). Assessment of annual high-water events for the Mackenzie River basin, Canada. Hydrological Processes, 22, 3864-3880. https://doi.org/ 10.1002/hyp.7016

Emmerton, C. A., Lesack, L. F. W., \& Marsh, P. (2007). Lake abundance, potential water storage, and habitat distribution in Mackenzie River Delta, western Canadian Arctic. Water Resources Research, 43. W05419. https://doi.org/10.1029/2006WR005139

ESRI (2016). ArcGIS 10.3.1 for Desktop. Redlands, CA: Environmental Systems Research Institute.

Fassnacht, S. R., \& Conly, F. M. (2000). Persistence of a scour hole in the East Channel of the Mackenzie Delta, NWT. Canadian Journal of Civil Engineering, 27, 798-804. https://doi.org/10.1139/100-022

Friend, P. F., \& Sinha, R. (1993). Braiding and meandering parameters. In J. L. Best, \& C. S. Bristow (Eds.), Braided rivers (pp. 105-111). Geological Society Special Publication 75.

Gay, G. R., Gay, W. H., Martinson, H. A., Meade, R. H., \& Moody, J. A. (1998). Evolution of cutoffs across meander necks in Powder River, Montana, USA. Earth Surface Processes and Landforms, 23, 651-662.

GDAL s.a.. gdal_polygonize.py. http://www.gdal.org/gdal_polygonize.html (6.6.2016)

Gilvear, D. J. (1999). Fluvial geomorphology and river engineering: Future roles utilizing a fluvial hydrosystems framework. Geomorphology, 31, 229-245. https://doi.org/10.1016/S0169-555X(99)00086-0

Goulding, H. L., Prowse, T. D., \& Beltaos, S. (2009). Spatial and temporal patterns of break-up and ice-jam flooding in the Mackenzie Delta, NWT. Hydrological Processes, 18, 2654-2670. https://doi.org/ 10.1002/hyp.7251
Goulding, H. L., Prowse, T. D., \& Bonsal, B. (2009). Hydroclimatic controls on the occurrence of break-up and ice-jam flooding in the Mackenzie Delta, NWT, Canada. Journal of Hydrology, 379, 251-267. https://doi. org/10.1016/j.jhydrol.2009.10.006

Grabowski, R. C., Surlan, N., \& Gurnell, A. M. (2014). Characterizing geomorphological change to support sustainable river restoration and management. WIREs Water, 1, 483-512. https://doi.org/10.1002/ wat2.1037

Hagen, D., Vistad, O. I., Eide, N. E., Flyen, A. C., \& Fangel, K. (2012). Managing visitor sites in Svalbard: From a precautionary approach towards knowledge-based management. Polar Research, 31, 18432. https:// doi.org/10.3402/polar.v31i0.18432

Henshaw, A. J., Gurnell, A. M., Bertoldi, W., \& Drake, N. A. (2013). An assessment of the degree to which Landsat TM data can support the assessment of fluvial dynamics, as revealed by changes in vegetation extent and channel position, along a large river. Geomorphology, 202, 74-85. https://doi.org/10.1016/j.geomorph.2013.01.011

Hill, P. R., Lewis, C. P., Desmarais, S., Kauppamythoo, V., \& Rais, H. (2001). The Mackenzie Delta: Sedimentary processed and facies of a highlatitude, fine-grained delta. Sedimentology, 48, 1047-1078. https:// doi.org/10.1046/j.1365-3091.2001.00408.x

Hooke, J. M. (1979). An analysis of the processes of river bank erosion. Journal of Hydrology, 42, 39-62. https://doi.org/10.1016/00221694(79)90005-2

Hooke, J. M. (2008). Temporal variations in fluvial processes on an active meandering river over a 20-year period. Geomorphology, 100, 3-13. https://doi.org/10.1016/j.geomorph.2007.04.034

IPCC (2015). Climate change 2014-Synthesis report. 151 p. Intergovernmental Panel on Climate Change, Geneva.

Jenner, K. A., \& Hill, P. R. (1998). Recent Arctic deltaic sedimentation, Oliver Islands, Mackenzie Delta, Northwest Territories, Canada. Sedimentaology, 45, 987-1004. https://doi.org/10.1046/j.13653091.1998.00193.x

Joeckel, R. M., \& Henebry, G. M. (2008). Channel and island change in the lower Platte River, Eastern Nebraska, USA: 1855-2005. Geomorphology, 102, 407-418. https://doi.org/10.1016/j.geomorph.2008.04.016

Karathanassi, V., lossifidis, C., \& Rokos, D. (1999). A thinning-based method for recognizing and extracting peri-urban road networks from SPOT panchromatic images. International Journal of Remote Sensing, 20, 153-168. https://doi.org/10.1080/014311699213668

Kokelj, S. V., \& Burn, C. R. (2005). Near-surface ground ice in sediments of the Mackenzie Delta, Northwest Territories, Canada. Permafrost and Periglacial Processes, 16, 291-303. https://doi.org/10.1002/ppp.537

Komsta, L. (2011). Outliers: Tests for outliers. R package version 0.14 . Available online: https://cran.r-project.org/web/packages/outliers/ index.html (12.10.2016)

Lesack, L. F. W., \& Marsh, P. (2007). Lengthening plus shortening of riverto-lake connection times in the Mackenzie River Delta respectively via two global change mechanisms along the arctic coast. Geophysical Research Letters, 34. L23404. https://doi.org/10.1029/2007GL031656

Lesack, L. F. W., Marsh, P., Hicks, F. E., \& Forbes, D. L. (2013). Timing, duration, and magnitude of peak annual water-levels during ice breakup in the Mackenzie Delta and the role of discharge. Water Resources Research, 49, 8234-8249. https://doi.org/10.1002/ 2012WR013198

Lesack, L. F. W., Marsh, P., Hicks, F. E., \& Forbes, D. L. (2014). Local spring warming drives earlier river-ice breakup in a large Arctic delta. Geophysical Research Letters, 41, 1560-1566. https://doi.org/10.1002/ 2013GL058761

Lindström, G., Pers, C. P., Rosberg, R., Strömqvist, J., \& Arheimer, B. (2010). Development and test of the HYPE (hydrological predictions for the environment) model-A water quality model for different spatial scales. Hydrology Research, 41, 295-319. https://doi.org/10.2166/ nh.2010.007

Lotsari, E., Wainwright, D., Corner, G. D., Alho, P., \& Käyhkö, J. (2014). Surveyed and modelled one-year morphodynamics in the braided lower 
Tana River. Hydrological Processes, 28, 2685-2716. https://doi.org/ 10.1002/hyp.9750

Lu, D., Mausel, P., Brondizio, E., \& Moran, E. (2004). Change detection techniques. International Journal of Remote Sensing, 25, 2365-2401. https://doi.org/10.1080/0143116031000139863

Luck, M., Maumenee, N., \& Whited, D. (2010). Remote sensing analysis of physical complexity of North Pacific Rim rivers to assist wild salmon conservation. Earth Surface Processes and Landforms, 35, 1330-1343. https://doi.org/10.1002/esp.2044

Mackay, J. R. (1963). The Mackenzie Delta Area, N.W.T. Canada, Geographical Branch, Memoir 8, republished 1974, Geological Survey of Canada, Miscellaneous Publication 23, 202 p. https://doi.org/ 10.1049/119932

Marsh, P., \& Hey, M. (1989). The flooding hydrology of Mackenzie Delta lakes near Inuvik, N.W.T., Canada. Arctic 42, 41-49. https://doi.org/ 10.14430/arctic1638

McDonald, D. M., \& Lamoureux, S. F. (2009). Hydroclimatic and channel snowpack controls over suspended sediment and grain size transport in a High Arctic catchment. Earth Surface Processes and Landforms, 34, 424-436. https://doi.org/10.1002/esp.1751

Mertes, L. A. K. (2002). Remote sensing of riverine landscapes. Freshwater Biology, 47, 799-816. https://doi.org/10.1046/j.13652427.2002.00909.x

Mouchot, M.-C., Alföldi, T., De Lisle, D., \& McCullough, G. (1991). Monitoring the water bodies of the Mackenzie delta by remote sensing methods. Arctic 44 Supplement, 21-28. https://doi.org/10.14430/ arctic1566

Nguyen, T.-N., Burn, C. R., King, D. J., \& Smith, S. L. (2009). Estimating the extent of near-surface permafrost using remote sensing, Mackenzie Delta, Northwest Territories. Permafrost and Periglacial Processes, 20, 141-153. https://doi.org/10.1002/ppp.637

Orton, G. J., \& Reading, H. G. (1993). Variability of deltaic processes in terms of sediment supply, with particular emphasis on grain size. Sedimentology, 40, 475-512. https://doi.org/10.1111/j.1365-3091.1993. tb01347.x

Palmer, M. A., Liermann, C. A. R., Nilsson, C., Flörke, M., Alcamo, J., Lake, P. S., \& Bond, N. (2008). Climate change and the world's river basins: Anticipating management options. Frontiers in Ecology and the Environment, 6, 81-89. https://doi.org/10.1890/060148

Peixoto, J. M. A., Nelson, B. W., \& Wittmann, F. (2009). Spatial and temporal dynamics of river channel migration and vegetation in central Amazonian white-water floodplains by remote-sensing techniques. Remote Sensing of Environment, 113, 2258-2266. https://doi.org/ 10.1016/j.rse.2009.06.015

Peterson, B. J., Holmes, R. M., McClelland, J. W., Vörösmarty, C. J., Lammers, R. B., Shiklomanov, A. I., ... Rahmstorf, S. (2002). Increasing river discharge to the Arctic Ocean. Science, 298, 2171-2173. https:// doi.org/10.1126/science.1077445

Petropoulos, G. P., Kalivas, D. P., Griffiths, H. M., \& Dimou, P. P. (2015). Remote sensing and GIS analysis for mapping spatio-temporal changes of erosion and deposition of two Mediterranean river deltas: The case of the Axios and Aliakmonas rivers, Greece. International Journal of Applied Earth Observation and Geoinformation, 35, 217-228. https:// doi.org/10.1016/j.jag.2014.08.004

QGIS s.a.. GDAL/OGR Geoprocessing. https://docs.qgis.org/2.8/en/docs/ user_manual/processing_algs/gdalogr/ogr_geoprocessing.html (7.6.2016)

QGIS Development Team (2016). QGIS Geographic Information System. Open Source Geospatial Foundation Project. http://qgis.osgeo.org (6.6.2016)

R Development Core Team (2016). R: A language and environment for statistical computing. R Foundation for Statistical Computing, Vienna, Austria. http://www.R-project.org/ (15.11.2016)

Richards, K. S. (1982). Rivers: Form and processes in alluvial channels. London: Methuen \& Co. Ltd.
Rozo, M. G., Nogueira, A. C. R., \& Castro, C. S. (2014). Remote sensingbased analysis of the planform changes in the Upper Amazon River over the period 1986-2006. Journal of South American Earth Sciences, 51, 28-44. https://doi.org/10.1016/j.jsames.2013.12.004

Schiffler, R. E. (1988). Maximum Z scores and outliers. The American Statistician, 42, 79-80.

Schindler, D. W., \& Smol, J. P. (2006). Cumulative effects of climate warming and other human activities on freshwaters of Arctic and subarctic North America. Ambio, 35, 160-168. https://doi.org/10.1579/ 0044-7447(2006)35[160:CEOCWA]2.0.CO;2

Schuur, E. A. G., Bockenheim, J., Canadell, J. P., Euskirchen, E., Field, C. B., Goryachkin, S. V., ... Zimov, S. A. (2008). Vulnerability of permafrost carbon to climate change: Implications for the global carbon cycle. Bioscience, 58, 701-714. https://doi.org/10.1641/B580807

Shiklomanov, A. I., Lammers, R. B., \& Vörösmarty, C. J. (2002). Widespread decline in hydrological monitoring threatens pan-arctic research. EOS Transactions, 83, 16-17. https://doi.org/10.1029/2002EO000007

Singh, A. (1989). Digital change detection techniques using remotelysensed data. International Journal of Remote Sensing, 10, 989-1003. https://doi.org/10.1080/01431168908903939

Smith, M. W. (1976). Permafrost in the Mackenzie Delta, Northwest Territories. Geological Survey: available from Information Canada.

Solomon, S. M., Forbes, D. L., Fraser, P., Moorman, B., Stevens, C. W., \& Whalen, D. (2008). Nearshore geohazards in the southern Beaufort Sea, Canada. In Proceedings of the 7th International Pipeline Conference, Calgary, paper IPC2008-64349. New York: American Society of Civil Engineers.

Strömqvist, J., Arheimer, B., Dahné, J., Donnelly, C., \& Lindström, G. (2012). Water and nutrient predictions in ungauged basins-Set-up and evaluation of a model at the national scale. Hydrological Sciences Journal, 57, 229-247. https://doi.org/10.1080/02626667.2011.637497

Syvitski, J. P. M. (1986). Estuaries, deltas and fjords of eastern Canada. Geoscience Canada, 13, 91-100.

U.S. Geological Survey (2016a). Product guide: Landsat 4-7 Climate Data Record (CDR) Surface Reflectance. http://landsat.usgs.gov/CDR_LSR. php (18.10.2016)

U.S. Geological Survey (2016b). Landsat processing details. http://landsat. usgs.gov/Landsat_Processing_Details.php (15.11.2016)

UNEP. United Nations environmental Programme (2007). Tourism in the polar regions-The sustainability challenge. 55 p. UNEP Sustainable Consumption and Production Branch and the International Ecotourism Society, Paris and Washington DC.

Walker, H. J. (1998). Arctic deltas. Journal of Coastal Research, 14, 718-738.

Walker, H. J. (1999). Landform development in an arctic delta: The roles of snow, ice and permafrost. In K. Hewitt, M.-L. Byrne, M. English, \& G. Young (Eds.), Landscapes of transition: Landform assemblages and transformations in cold regions (pp. 159-183). GeoJournal Library 68.

Walker, H. J., \& Hudson, P. F. (2003). Hydrologic and geomorphic processes in the Colville River delta, Alaska. Geomorphology, 56, 291-303. https:// doi.org/10.1016/S0169-555X(03)00157-0

Williams, P. J., \& Wallis, M. (1995). Permafrost and climate changeGeotechnical implications. Philosophical Transactions of the Royal Society A: Mathematical, Physical and Engineering Sciences, 352, 347-358. https://doi.org/10.1098/rsta.1995.0075

Woo, M. K., \& Thorne, R. (2003). Streamflow in the Mackenzie Basin, Canada. Arctic 56, 328-340. https://doi.org/10.14430/arctic630

Wu, Y., Sheng, Y., Wang, Y., Jin, H., \& Chen, W. (2010). Stresses and deformations in a buried oil pipeline subject to differential frost heave in permafrost regions. Cold Regions Science and Technology, 64, 256-261. https://doi.org/10.1016/j.coldregions.2010.07.004

Wyzga, B. (1993). River response to channel regulation: Case study of the Raba river, Carpathians, Poland. Earth Surface Processes and Landforms, 18, 541-556. https://doi.org/10.1002/esp.3290180607 
Yang, C., Cai, X., Wang, X., Yan, R., Zhang, T., Zhang, Q., \& Lu, X. (2015). Remotely sensed trajectory analysis of channel migration in lower Jingjiang reach during the period of 1983-2013. Remote Sensing, 7, 16241-16256. https://doi.org/10.3390/rs71215828

Yang, D., Shi, X., \& Marsh, P. (2015). Variability and extreme of Mackenzie River daily discharge during 1973-2011. Quaternary International, 380-381, 159-168. https://doi.org/10.1016/j.quaint. 2014.09.023

Zhan, C. (1993). A hybrid line thinning approach. Auto-Carto 11, 396-405. Proceedings of the Eleventh International Symposium on Computer-Assisted Cartography, Minneapolis, 30.10.-1.11.1993. American Society for Photogrammetry and Remote Sensing, American Congress on Surveying and Mapping, Bethesda.

\section{SUPPORTING INFORMATION}

Additional Supporting Information may be found online in the supporting information tab for this article.

How to cite this article: Vesakoski J-M, Nylén T, Arheimer B, et al. Arctic Mackenzie Delta channel planform evolution during 1983-2013 utilising Landsat data and hydrological time series. Hydrological Processes. 2017;31:3979-3995. https:// doi.org/10.1002/hyp.11315 